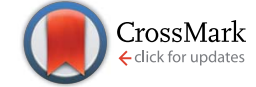

Cite this: RSC Adv., 2017, 7, 1401

Received 20th October 2016 Accepted 21st November 2016

DOI: $10.1039 / \mathrm{c} 6 \mathrm{ra} 25535 \mathrm{c}$

www.rsc.org/advances

\section{Structural, electronic and optical properties of 2,5- dichloro- $p$-xylene: experimental and theoretical calculations using DFT method $\uparrow$}

\begin{abstract}
G. Venkatesh, ${ }^{\star a}$ M. Govindaraju, ${ }^{\text {b C. Kamal, }}{ }^{c}$ P. Vennila ${ }^{d}$ and S. Kaya ${ }^{e}$
The vibrational spectra including FT-IR and FT-Raman for 2,5-dichloro-p-xylene (DCPX) have been recorded. All the energies, the geometry of the compound and vibrational frequencies of (DCPX) have been calculated using density functional theory (DFT/B3LYP) method coupled with 6-31G* and 6$311+G^{* *}$ functionals. The occurrence of charge transfer was known from the HOMO-LUMO energy gap of DCPX. In order to find out the electronic excitation energies, oscillator strength and nature of the respective excited states, the closed-shell singlet calculation method has been utilized for DCPX. The values of the total dipole moment $(\mu)$ and the first order hyperpolarizability $(\beta)$ of DCPX have been investigated. The non-linear optical (NLO) behavior of DCPX has been identified from the results of hyperpolarizability values.
\end{abstract}

\section{Introduction}

Xylene is an aromatic hydrocarbon which has two methyl groups substituted in benzene at various positions. Xylene is a major petrochemical produced by the carbonisation of coal in the manufacturing of coke fuel, which represents about $0.5-1 \%$ of crude oil and is established in a small amount in gasoline and aircraft fuels. $p$-Xylene is a benzene based aromatic hydrocarbon having two substituted methyl groups with the molecular formula $\mathrm{C}_{8} \mathrm{H}_{10}$ or $\mathrm{C}_{6} \mathrm{H}_{4}\left(\mathrm{CH}_{3}\right)_{2}$. The position of the two methyl groups in the aromatic ring has been identified from the symbol " $p$ " which revealed it as para position. Xylene is used on a large scale for the manufacture of terephthalic acid for polyester. ${ }^{1-4}$

Xylene is the principal precursor to terephthalic acid and dimethyl terephthalate, both are used in the production of polyethylene terephthalate (PET) plastic bottles and polyester clothing. It is widely used as a solvent in the leather, rubber and printing industries. Xylene is used as a sealer/carrier solvent in acrylic concrete which is a widely used concrete protector..$^{5-9}$ Arjunan et al., examined the vibrational properties of 4-nitro

${ }^{a} R \& D$ Centre, Bharathiar University, Coimbatore-641 046, India. E-mail: venkateshindhuja@gmail.com; Tel: +919965285541

${ }^{b}$ Department of Chemistry, Arignar Anna Government Arts College, Namakkal-638 052, India

'Department of Chemistry, VSA Group of Institutions, Salem, Tamil Nadu-636010, India

${ }^{d}$ Department of Chemistry, Thiruvalluvar Government Arts College, Rasipuram-638 052, India

${ }^{e}$ Department of Chemistry, Cumhuriyet University, Sivas-58140, Turkey

$\dagger$ Electronic supplementary information (ESI) available. See DOI: $10.1039 / \mathrm{c} 6 \mathrm{ra} 25535 \mathrm{c}$ and 5-nitro- $m$-xylene. ${ }^{10}$ Govindarajan and his co-workers have reported vibrational, spectral and NLO properties of 2-chloroxylene. ${ }^{11}$ Chemical properties and anticancer activity of $\alpha, \alpha, \alpha^{\prime}, \alpha^{\prime}$ tetra bromo- $p$-xylene were reported by M. Manzoor ali and his co-workers. ${ }^{12}$ Arivazhagan et al., reported the vibrational spectroscopic studies of 4-bromo-o-xylene. ${ }^{13}$

True to the best of our knowledge, the structural features and vibrational analysis of 2,5-dichloro xylene by DFT methods have not been reported, so far. Thus, considering the industrial importance of xylene derivatives, the experimental and theoretical calculation of DCPX using DFT method with the B3LYP (Becke's three-parameter (B3) Lee-Yang-Parr's (LYP) correlation exchange in functional) functional has been reported in the present study with a view to explore the structural characteristics. ${ }^{14,15}$ Quantum chemical computational methods have been proved to be very significant in interpreting and assuming the vibrational spectra, recent past. For instance, a complete vibrational and molecular structure analysis of 2-methoxy-5nitrophenol and 2-methoxy-4-methylphenol isomers has been evaluated using quantum mechanical approach by HF and DFT calculations by Meenakshi. ${ }^{16}$ Spectroscopic, single crystal XRD structure, DFT and molecular dynamics investigation of Sheena mary et al., examined 1-(3-chloro-4-fluorophenyl)-3-[3(trifluoromethyl)phenyl]thiourea using DFT for it molecular dynamics. ${ }^{17}$ DFT has also been applied to examine the structural features, NLO properties of heterocyclic 5-nitro-1,3benzodioxole and its applications on solar cells. ${ }^{18}$

A significant development has been achieved by combining the empirical method with DFT information in the scaled quantum mechanical (SQM) force field method. In SQM approach, the deviations of the computed harmonic force field are rectified using some scale factors which are found to be well 
transferable between chemically related molecules and they were preferred to use. The calculated IR and Raman vibrational spectral assessment of DCPX were also simulated using the computed dipole moments for IR intensities and polarizabilities for Raman intensities.

\section{Experimental details}

DCPX as finely powdered solid was obtained from Lancaster Chemical Company of UK. The FT-IR spectra of DCPX have been recorded using $\mathrm{KBr}$ pellet technique in the region 4000-400 $\mathrm{cm}^{-1}$ with a resolution of $1 \mathrm{~cm}^{-1}$ using BRUKER IFS $66 \mathrm{~V}$ spectrophotometer coupled with $\mathrm{He}-\mathrm{Ne}$ laser source at room temperature. The FT-Raman spectra has also been recorded on a same instrument equipped with FRA-106 FT-Raman accessory in $4000-100 \mathrm{~cm}^{-1}$ stoke region with $1064 \mathrm{~nm}$ line of a Nd:YAG Laser for excitation which is operating at $200 \mathrm{~mW}$ power. The minimal accuracy of wave numbers was assumed to be $\pm 1 \mathrm{~cm}^{-1}$.

\section{Computational details}

To provide the complete information regarding the molecular structural characteristics and the fundamental vibrational modes of DCPX, the restricted DFT-B3LYP correlation functional calculations have been carried out. ${ }^{\mathbf{1 4 , 1 5}}$ The calculations of geometrical parameters in the ground state were performed using the GAUSSIAN 09W programs. The geometry optimization was carried out using the initial geometry generated from standard geometrical parameters and B3LYP methods adopting $6-31 \mathrm{G}^{*} / 6-311+\mathrm{G}^{* *}$ functional to characterize all stationary points as minima. The optimized structural parameters of the compound were used for harmonic vibrational frequency calculations resulting in IR and Raman frequencies together with intensities and Raman depolarization ratios. In DFT methods, Becke's three parameter exchange-functional (B3) jointed with gradientcorrected correlation functional of Lee, Yang and Parr (LYP) by employ the split-valence polarized $6-311+\mathrm{G}^{* *}$ functional have been developed for the computation of molecular structure optimization, vibrational frequencies and energies of the molecular optimized structures.

The vibrational modes were assigned by means of visual inspection using the GAUSSVIEW program. The symmetry of the vibrational modes was determined by standard procedure of decomposition of the traces of the symmetry operations into the irreducible representations. The derivation (given below) obtained from the theory of Raman scattering has been utilized to convert the Raman activities $\left(S_{\mathrm{i}}\right)$ calculated by GAUSSIAN 09W program into relative Raman intensities $\left(I_{\mathrm{i}}\right)$

$$
I_{\mathrm{i}}=\frac{f\left(v_{0}-v_{\mathrm{i}}\right)^{4} S_{\mathrm{i}}}{v_{\mathrm{i}}[1-\exp (-h c v / K T)]}
$$

where, $v_{0}$ and $v_{\mathrm{i}}$ are exciting frequency $\left(\mathrm{in}^{-1}\right.$ ) and vibrational wavenumber of the normal mode, respectively; $h, c \& k$ represent universal constants and $f$ stands for common normalization factor chosen for all peak intensities.

\section{Results and discussion}

\subsection{Geometrical parameters}

DCPX contains two methyl groups at para position and two chlorine atoms in aromatic benzene ring. The optimized molecular structure has been obtained from Gaussion09W program. ${ }^{19}$ The non linear molecular structure of DCPX illustrates $C_{\mathrm{s}}$ symmetry (Fig. 1). The global minimum energy has been obtained by the DFT molecular optimization structure and is given in Table S1 ESI. $\dagger$ The obtained energies are as follows -1229.95 (Hartee) B3LYP/6-31G* , -1230.07 (Hartee) by B3LYP/6$311 \mathrm{G}^{* *}$ for gaseous phase and -1229.54 (Hartee) by B3LYP/6$311 \mathrm{G}^{* *}-1230.09$ (Hartee) aqueous phase. Table 1 compares the theoretically calculated bond lengths, bond angles and dihedral angles with X-ray data values. The optimized bond lengths are in the order as follows C2-C3 $<$ C5-C6 $<$ C1-C2 $<$ C4-C5 $<$ C1-C6 $<$ C3-C4. It is clear from Table 1 that, the carbons substituted by methyl groups have larger bond lengths and the carbons substituted by halogens possess lower bond lengths when compared to all other ring atoms. ${ }^{10,12,20}$ This could be due to the inductive effect of methyl group and chlorine atoms as well as resonance effect of phenyl ring (substitution effect). $+I$ effect of methyl group pushed out the electrons towards the phenyl ring. But, the $-I$ effect of chlorine atoms and resonance effect of phenyl ring competed with each other to pull the electrons towards themselves. These effects resulted in larger bond lengths of carbons substituted by methyl group meanwhile shorter bond lengths of carbons substituted by halogen atoms. ${ }^{21,22}$ From the bond lengths, it is clearly known that, the aromatic ring is slightly distorted from perfect hexagonal structure. It could be due to the

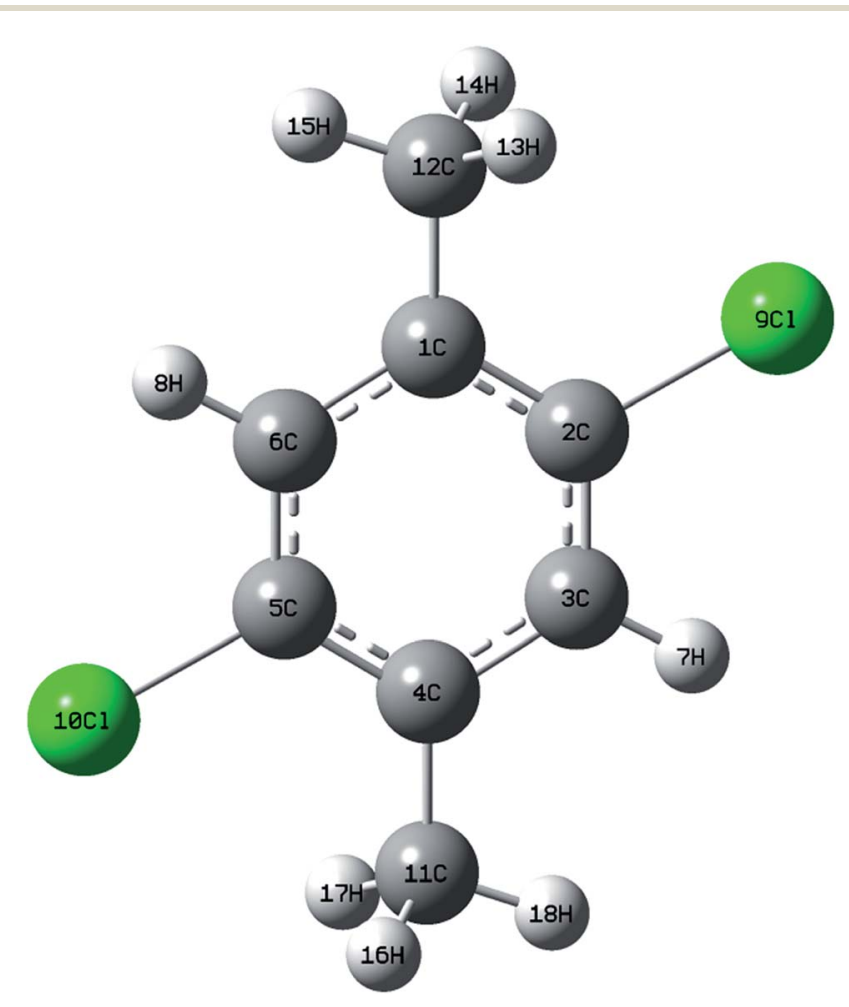

Fig. 1 Optimized molecular structure of DCPX. 
Table 1 Optimized geometrical parameters of DCPX obtained by B3LYP/6-31G*, B3LYP/6-311G** methods in gaseous phase and B3LYP/6311G** method in aqueous phase using DFT calculations

\begin{tabular}{|c|c|c|c|c|c|c|}
\hline \multicolumn{4}{|l|}{ Gaseous phase } & \multirow{2}{*}{\multicolumn{2}{|c|}{$\begin{array}{l}\text { Aqueous phase } \\
\text { B3LYP/6-311G** }\end{array}$}} & \multirow{3}{*}{$\begin{array}{l}\text { X-ray data } \\
\text { values }(\AA)\end{array}$} \\
\hline \multicolumn{2}{|l|}{ B3LYP/6-31G* } & \multicolumn{2}{|c|}{ B3LYP/6-311G** } & & & \\
\hline Bond length & Value (̊̊) & Bond length & Value (̊̊) & Bond length & Value $(\AA)$ & \\
\hline $\mathrm{C}_{1}-\mathrm{C}_{2}$ & 1.389 & $\mathrm{C}_{1}-\mathrm{C}_{2}$ & 1.396 & $\mathrm{C}_{1}-\mathrm{C}_{2}$ & 1.396 & 1.399 \\
\hline $\mathrm{C}_{1}-\mathrm{C}_{6}$ & 1.398 & $\mathrm{C}_{1}-\mathrm{C}_{6}$ & 1.403 & $\mathrm{C}_{1}-\mathrm{C}_{6}$ & 1.402 & 1.399 \\
\hline $\mathrm{C}_{1}-\mathrm{C}_{11}$ & 1.508 & $\mathrm{C}_{1}-\mathrm{C}_{11}$ & 1.507 & $\mathrm{C}_{1}-\mathrm{C}_{11}$ & 1.507 & 1.511 \\
\hline $\mathrm{C}_{2}-\mathrm{C}_{3}$ & 1.381 & $\mathrm{C}_{2}-\mathrm{C}_{3}$ & 1.387 & $\mathrm{C}_{2}-\mathrm{C}_{3}$ & 1.386 & 1.399 \\
\hline $\mathrm{C}_{2}-\mathrm{Cl}_{9}$ & 1.831 & $\mathrm{C}_{2}-\mathrm{Cl}_{9}$ & 1.835 & $\mathrm{C}_{2}-\mathrm{Cl}_{9}$ & 1.836 & 1.771 \\
\hline $\mathrm{C}_{3}-\mathrm{C}_{4}$ & 1.406 & $\mathrm{C}_{3}-\mathrm{C}_{4}$ & 1.405 & $\mathrm{C}_{3}-\mathrm{C}_{4}$ & 1.405 & 1.399 \\
\hline $\mathrm{C}_{3}-\mathrm{H}_{7}$ & 1.083 & $\mathrm{C}_{3}-\mathrm{H}_{7}$ & 1.080 & $\mathrm{C}_{3}-\mathrm{H}_{7}$ & 1.080 & 1.098 \\
\hline $\mathrm{C}_{4}-\mathrm{C}_{5}$ & 1.391 & $\mathrm{C}_{4}-\mathrm{C}_{5}$ & 1.398 & $\mathrm{C}_{4}-\mathrm{C}_{5}$ & 1.397 & 1.399 \\
\hline $\mathrm{C}_{4}-\mathrm{C}_{12}$ & 1.508 & $\mathrm{C}_{4}-\mathrm{C}_{12}$ & 1.507 & $\mathrm{C}_{4}-\mathrm{C}_{12}$ & 1.507 & 1.511 \\
\hline $\mathrm{C}_{5}-\mathrm{C}_{6}$ & 1.383 & $\mathrm{C}_{5}-\mathrm{C}_{6}$ & 1.389 & $\mathrm{C}_{5}-\mathrm{C}_{6}$ & 1.388 & 1.399 \\
\hline $\mathrm{C}_{5}-\mathrm{Cl}_{10}$ & 1.831 & $\mathrm{C}_{5}-\mathrm{Cl}_{10}$ & 1.835 & $\mathrm{C}_{5}-\mathrm{Cl}_{10}$ & 1.836 & 1.771 \\
\hline $\mathrm{C}_{6}-\mathrm{H}_{8}$ & 1.083 & $\mathrm{C}_{6}-\mathrm{H}_{8}$ & 1.080 & $\mathrm{C}_{6}-\mathrm{H}_{8}$ & 1.080 & 1.098 \\
\hline $\mathrm{C}_{11}-\mathrm{H}_{13}$ & 1.096 & $\mathrm{C}_{11}-\mathrm{H}_{13}$ & 1.092 & $\mathrm{C}_{11}-\mathrm{H}_{13}$ & 1.092 & 1.120 \\
\hline $\mathrm{C}_{11}-\mathrm{H}_{14}$ & 1.096 & $\mathrm{C}_{11}-\mathrm{H}_{14}$ & 1.092 & $\mathrm{C}_{11}-\mathrm{H}_{14}$ & 1.092 & 1.120 \\
\hline $\mathrm{C}_{11}-\mathrm{H}_{15}$ & 1.093 & $\mathrm{C}_{11}-\mathrm{H}_{15}$ & 1.090 & $\mathrm{C}_{11}-\mathrm{H}_{15}$ & 1.088 & 1.120 \\
\hline $\mathrm{C}_{12}-\mathrm{H}_{16}$ & 1.096 & $\mathrm{C}_{12}-\mathrm{H}_{16}$ & 1.092 & $\mathrm{C}_{12}-\mathrm{H}_{16}$ & 1.092 & 1.120 \\
\hline $\mathrm{C}_{12}-\mathrm{H}_{17}$ & 1.093 & $\mathrm{C}_{12}-\mathrm{H}_{17}$ & 1.090 & $\mathrm{C}_{12}-\mathrm{H}_{17}$ & 1.088 & 1.120 \\
\hline $\mathrm{C}_{12}-\mathrm{H}_{18}$ & 1.096 & $\mathrm{C}_{12}-\mathrm{H}_{18}$ & 1.092 & $\mathrm{C}_{12}-\mathrm{H}_{18}$ & 1.092 & 1.120 \\
\hline Bond angle & Value $\left(^{\circ}\right)$ & Bond angle & Value $\left(^{\circ}\right)$ & Bond angle & Value $\left(^{\circ}\right)$ & $\begin{array}{l}\text { X-ray data } \\
\text { values }(\AA)\end{array}$ \\
\hline $\mathrm{C}_{2}-\mathrm{C}_{1}-\mathrm{C}_{6}$ & 117.130 & $\mathrm{C}_{2}-\mathrm{C}_{1}-\mathrm{C}_{6}$ & 117.059 & $\mathrm{C}_{2}-\mathrm{C}_{1}-\mathrm{C}_{6}$ & 117.124 & 118.6 \\
\hline $\mathrm{C}_{2}-\mathrm{C}_{1}-\mathrm{C}_{11}$ & 120.945 & $\mathrm{C}_{2}-\mathrm{C}_{1}-\mathrm{C}_{11}$ & 120.008 & $\mathrm{C}_{2}-\mathrm{C}_{1}-\mathrm{C}_{11}$ & 120.346 & - \\
\hline $\mathrm{C}_{6}-\mathrm{C}_{1}-\mathrm{C}_{11}$ & 120.925 & $\mathrm{C}_{6}-\mathrm{C}_{1}-\mathrm{C}_{11}$ & 120.983 & $\mathrm{C}_{6}-\mathrm{C}_{1}-\mathrm{C}_{11}$ & 120.930 & - \\
\hline $\mathrm{C}_{1}-\mathrm{C}_{2}-\mathrm{C}_{3}$ & 121.574 & $\mathrm{C}_{1}-\mathrm{C}_{2}-\mathrm{C}_{3}$ & 121.691 & $\mathrm{C}_{1}-\mathrm{C}_{2}-\mathrm{C}_{3}$ & 121.683 & 120.0 \\
\hline $\mathrm{C}_{1}-\mathrm{C}_{2}-\mathrm{Cl}_{9}$ & 119.333 & $\mathrm{C}_{1}-\mathrm{C}_{2}-\mathrm{Cl}_{9}$ & 119.281 & $\mathrm{C}_{1}-\mathrm{C}_{2}-\mathrm{Cl}_{9}$ & 119.063 & - \\
\hline $\mathrm{C}_{3}-\mathrm{C}_{2}-\mathrm{Cl}_{9}$ & 118.623 & $\mathrm{C}_{3}-\mathrm{C}_{2}-\mathrm{Cl}_{9}$ & 117.528 & $\mathrm{C}_{3}-\mathrm{C}_{2}-\mathrm{Cl}_{9}$ & 117.255 & - \\
\hline $\mathrm{C}_{2}-\mathrm{C}_{3}-\mathrm{C}_{4}$ & 119.326 & $\mathrm{C}_{2}-\mathrm{C}_{3}-\mathrm{C}_{4}$ & 119.320 & $\mathrm{C}_{2}-\mathrm{C}_{3}-\mathrm{C}_{4}$ & 119.393 & 120.0 \\
\hline $\mathrm{C}_{2}-\mathrm{C}_{3}-\mathrm{H}_{7}$ & 119.740 & $\mathrm{C}_{2}-\mathrm{C}_{3}-\mathrm{H}_{7}$ & 119.746 & $\mathrm{C}_{2}-\mathrm{C}_{3}-\mathrm{H}_{7}$ & 120.123 & - \\
\hline $\mathrm{C}_{4}-\mathrm{C}_{3}-\mathrm{H}_{7}$ & 119.433 & $\mathrm{C}_{4}-\mathrm{C}_{3}-\mathrm{H}_{7}$ & 119.455 & $\mathrm{C}_{4}-\mathrm{C}_{3}-\mathrm{H}_{7}$ & 119.283 & - \\
\hline $\mathrm{C}_{3}-\mathrm{C}_{4}-\mathrm{C}_{5}$ & 117.130 & $\mathrm{C}_{3}-\mathrm{C}_{4}-\mathrm{C}_{5}$ & 117.069 & $\mathrm{C}_{3}-\mathrm{C}_{4}-\mathrm{C}_{5}$ & 111.124 & 120.0 \\
\hline $\mathrm{C}_{3}-\mathrm{C}_{4}-\mathrm{C}_{12}$ & 120.925 & $\mathrm{C}_{3}-\mathrm{C}_{4}-\mathrm{C}_{12}$ & 120.983 & $\mathrm{C}_{3}-\mathrm{C}_{4}-\mathrm{C}_{12}$ & 120.930 & - \\
\hline $\mathrm{C}_{5}-\mathrm{C}_{4}-\mathrm{C}_{12}$ & 120.945 & $\mathrm{C}_{5}-\mathrm{C}_{4}-\mathrm{C}_{12}$ & 120.008 & $\mathrm{C}_{5}-\mathrm{C}_{4}-\mathrm{C}_{12}$ & 120.346 & - \\
\hline $\mathrm{C}_{4}-\mathrm{C}_{5}-\mathrm{C}_{6}$ & 119.044 & $\mathrm{C}_{4}-\mathrm{C}_{5}-\mathrm{C}_{6}$ & 119.191 & $\mathrm{C}_{4}-\mathrm{C}_{5}-\mathrm{C}_{6}$ & 119.683 & 120.0 \\
\hline $\mathrm{C}_{4}-\mathrm{C}_{5}-\mathrm{Cl}_{10}$ & 119.333 & $\mathrm{C}_{4}-\mathrm{C}_{5}-\mathrm{Cl}_{10}$ & 119.281 & $\mathrm{C}_{4}-\mathrm{C}_{5}-\mathrm{Cl}_{10}$ & 119.063 & - \\
\hline $\mathrm{C}_{6}-\mathrm{C}_{5}-\mathrm{Cl}_{10}$ & 118.623 & $\mathrm{C}_{6}-\mathrm{C}_{5}-\mathrm{Cl}_{10}$ & 118.528 & $\mathrm{C}_{6}-\mathrm{C}_{5}-\mathrm{Cl}_{10}$ & 118.255 & - \\
\hline $\mathrm{C}_{1}-\mathrm{C}_{6}-\mathrm{C}_{5}$ & 119.326 & $\mathrm{C}_{1}-\mathrm{C}_{6}-\mathrm{C}_{5}$ & 119.390 & $\mathrm{C}_{1}-\mathrm{C}_{6}-\mathrm{C}_{5}$ & 119.393 & 120.0 \\
\hline $\mathrm{C}_{1}-\mathrm{C}_{6}-\mathrm{H}_{8}$ & 119.433 & $\mathrm{C}_{1}-\mathrm{C}_{6}-\mathrm{H}_{8}$ & 119.455 & $\mathrm{C}_{1}-\mathrm{C}_{6}-\mathrm{H}_{8}$ & 119.283 & - \\
\hline $\mathrm{C}_{5}-\mathrm{C}_{6}-\mathrm{H}_{8}$ & 119.740 & $\mathrm{C}_{5}-\mathrm{C}_{6}-\mathrm{H}_{8}$ & 119.746 & $\mathrm{C}_{5}-\mathrm{C}_{6}-\mathrm{H}_{8}$ & 120.123 & - \\
\hline $\mathrm{C}_{1}-\mathrm{C}_{11}-\mathrm{H}_{13}$ & 110.273 & $\mathrm{C}_{1}-\mathrm{C}_{11}-\mathrm{H}_{13}$ & 111.307 & $\mathrm{C}_{1}-\mathrm{C}_{11}-\mathrm{H}_{13}$ & 111.271 & - \\
\hline $\mathrm{C}_{1}-\mathrm{C}_{11}-\mathrm{H}_{14}$ & 111.271 & $\mathrm{C}_{1}-\mathrm{C}_{11}-\mathrm{H}_{14}$ & 111.304 & $\mathrm{C}_{1}-\mathrm{C}_{11}-\mathrm{H}_{14}$ & 111.270 & - \\
\hline $\mathrm{C}_{1}-\mathrm{C}_{11}-\mathrm{H}_{15}$ & 110.763 & $\mathrm{C}_{1}-\mathrm{C}_{11}-\mathrm{H}_{15}$ & 110.744 & $\mathrm{C}_{1}-\mathrm{C}_{11}-\mathrm{H}_{15}$ & 110.706 & - \\
\hline $\mathrm{H}_{13}-\mathrm{C}_{11}-\mathrm{H}_{14}$ & 109.851 & $\mathrm{H}_{13}-\mathrm{C}_{11}-\mathrm{H}_{14}$ & 109.906 & $\mathrm{H}_{13}-\mathrm{C}_{11}-\mathrm{H}_{14}$ & 109.101 & - \\
\hline $\mathrm{H}_{13}-\mathrm{C}_{11}-\mathrm{H}_{15}$ & 108.258 & $\mathrm{H}_{13}-\mathrm{C}_{11}-\mathrm{H}_{15}$ & 108.206 & $\mathrm{H}_{13}-\mathrm{C}_{11}-\mathrm{H}_{15}$ & 108.165 & - \\
\hline $\mathrm{H}_{14}-\mathrm{C}_{11}-\mathrm{H}_{15}$ & 108.268 & $\mathrm{H}_{14}-\mathrm{C}_{11}-\mathrm{H}_{15}$ & 108.215 & $\mathrm{H}_{14}-\mathrm{C}_{11}-\mathrm{H}_{15}$ & 108.175 & - \\
\hline $\mathrm{C}_{4}-\mathrm{C}_{12}-\mathrm{H}_{16}$ & 111.271 & $\mathrm{C}_{4}-\mathrm{C}_{12}-\mathrm{H}_{16}$ & 111.304 & $\mathrm{C}_{4}-\mathrm{C}_{12}-\mathrm{H}_{16}$ & 111.270 & - \\
\hline $\mathrm{C}_{4}-\mathrm{C}_{12}-\mathrm{H}_{17}$ & 110.763 & $\mathrm{C}_{4}-\mathrm{C}_{12}-\mathrm{H}_{17}$ & 110.744 & $\mathrm{C}_{4}-\mathrm{C}_{12}-\mathrm{H}_{17}$ & 110.706 & - \\
\hline $\mathrm{C}_{4}-\mathrm{C}_{12}-\mathrm{H}_{18}$ & 111.273 & $\mathrm{C}_{4}-\mathrm{C}_{12}-\mathrm{H}_{18}$ & 111.307 & $\mathrm{C}_{4}-\mathrm{C}_{12}-\mathrm{H}_{18}$ & 111.271 & - \\
\hline $\mathrm{H}_{16}-\mathrm{C}_{12}-\mathrm{H}_{17}$ & 108.268 & $\mathrm{H}_{16}-\mathrm{C}_{12}-\mathrm{H}_{17}$ & 108.215 & $\mathrm{H}_{16}-\mathrm{C}_{12}-\mathrm{H}_{17}$ & 108.175 & - \\
\hline $\mathrm{H}_{16}-\mathrm{C}_{12}-\mathrm{H}_{18}$ & 107.851 & $\mathrm{H}_{16}-\mathrm{C}_{12}-\mathrm{H}_{18}$ & 107.906 & $\mathrm{H}_{16}-\mathrm{C}_{12}-\mathrm{H}_{18}$ & 107.101 & - \\
\hline $\mathrm{H}_{17}-\mathrm{C}_{12}-\mathrm{H}_{18}$ & 108.258 & $\mathrm{H}_{17}-\mathrm{C}_{12}-\mathrm{H}_{18}$ & 108.206 & $\mathrm{H}_{17}-\mathrm{C}_{12}-\mathrm{H}_{18}$ & 108.165 & - \\
\hline Dihedral angle & Value $\left(^{\circ}\right)$ & Dihedral angle & Value $\left(^{\circ}\right)$ & Dihedral angle & Value $\left(^{\circ}\right)$ & - \\
\hline $\mathrm{C}_{6}-\mathrm{C}_{1}-\mathrm{C}_{2}-\mathrm{C}_{3}$ & 0.013 & $\mathrm{C}_{6}-\mathrm{C}_{1}-\mathrm{C}_{2}-\mathrm{C}_{3}$ & 0.025 & $\mathrm{C}_{6}-\mathrm{C}_{1}-\mathrm{C}_{2}-\mathrm{C}_{3}$ & 0.016 & - \\
\hline $\mathrm{C}_{6}-\mathrm{C}_{1}-\mathrm{C}_{2}-\mathrm{Cl}_{9}$ & -179.981 & $\mathrm{C}_{6}-\mathrm{C}_{1}-\mathrm{C}_{2}-\mathrm{Cl}_{9}$ & -179.990 & $\mathrm{C}_{6}-\mathrm{C}_{1}-\mathrm{C}_{2}-\mathrm{Cl}_{9}$ & -179.980 & - \\
\hline $\mathrm{C}_{11}-\mathrm{C}_{1}-\mathrm{C}_{2}-\mathrm{C}_{3}$ & 179.992 & $\mathrm{C}_{11}-\mathrm{C}_{1}-\mathrm{C}_{2}-\mathrm{C}_{3}$ & 180.009 & $\mathrm{C}_{11}-\mathrm{C}_{1}-\mathrm{C}_{2}-\mathrm{C}_{3}$ & 179.999 & - \\
\hline
\end{tabular}


Table 1 (Contd.)

\begin{tabular}{|c|c|c|c|c|c|c|}
\hline Dihedral angle & Value $\left(^{\circ}\right)$ & Dihedral angle & Value $\left(^{\circ}\right)$ & Dihedral angle & Value $\left(^{\circ}\right)$ & - \\
\hline $\mathrm{C}_{11}-\mathrm{C}_{1}-\mathrm{C}_{2}-\mathrm{Cl}_{9}$ & -0.003 & $\mathrm{C}_{11}-\mathrm{C}_{1}-\mathrm{C}_{2}-\mathrm{Cl}_{9}$ & -0.008 & $\mathrm{C}_{11}-\mathrm{C}_{1}-\mathrm{C}_{2}-\mathrm{Cl}_{9}$ & -0.001 & - \\
\hline $\mathrm{C}_{2}-\mathrm{C}_{1}-\mathrm{C}_{6}-\mathrm{C}_{5}$ & -0.014 & $\mathrm{C}_{2}-\mathrm{C}_{1}-\mathrm{C}_{6}-\mathrm{C}_{5}$ & -0.014 & $\mathrm{C}_{2}-\mathrm{C}_{1}-\mathrm{C}_{6}-\mathrm{C}_{5}$ & -0.013 & - \\
\hline $\mathrm{C}_{11}-\mathrm{C}_{1}-\mathrm{C}_{6}-\mathrm{C}_{5}$ & -179.993 & $\mathrm{C}_{11}-\mathrm{C}_{1}-\mathrm{C}_{6}-\mathrm{C}_{5}$ & -180.000 & $\mathrm{C}_{11}-\mathrm{C}_{1}-\mathrm{C}_{6}-\mathrm{C}_{5}$ & -180.000 & - \\
\hline $\mathrm{C}_{11}-\mathrm{C}_{1}-\mathrm{C}_{6}-\mathrm{H}_{8}$ & 0.013 & $\mathrm{C}_{11}-\mathrm{C}_{1}-\mathrm{C}_{6}-\mathrm{H}_{8}$ & 0.011 & $\mathrm{C}_{11}-\mathrm{C}_{1}-\mathrm{C}_{6}-\mathrm{H}_{8}$ & 0.014 & - \\
\hline $\mathrm{C}_{2}-\mathrm{C}_{1}-\mathrm{C}_{11}-\mathrm{H}_{13}$ & -59.519 & $\mathrm{C}_{2}-\mathrm{C}_{1}-\mathrm{C}_{11}-\mathrm{H}_{13}$ & -59.577 & $\mathrm{C}_{2}-\mathrm{C}_{1}-\mathrm{C}_{11}-\mathrm{H}_{13}$ & -59.687 & - \\
\hline $\mathrm{C}_{6}-\mathrm{C}_{1}-\mathrm{C}_{11}-\mathrm{H}_{13}$ & 120.459 & $\mathrm{C}_{6}-\mathrm{C}_{1}-\mathrm{C}_{11}-\mathrm{H}_{13}$ & 120.405 & $\mathrm{C}_{6}-\mathrm{C}_{1}-\mathrm{C}_{11}-\mathrm{H}_{13}$ & 120.295 & - \\
\hline $\mathrm{C}_{6}-\mathrm{C}_{1}-\mathrm{C}_{11}-\mathrm{H}_{14}$ & -120.502 & $\mathrm{C}_{6}-\mathrm{C}_{1}-\mathrm{C}_{11}-\mathrm{H}_{14}$ & -120.440 & $\mathrm{C}_{6}-\mathrm{C}_{1}-\mathrm{C}_{11}-\mathrm{H}_{14}$ & -120.350 & - \\
\hline $\mathrm{C}_{6}-\mathrm{C}_{1}-\mathrm{C}_{11}-\mathrm{H}_{15}$ & -0.016 & $\mathrm{C}_{6}-\mathrm{C}_{1}-\mathrm{C}_{11}-\mathrm{H}_{15}$ & -0.014 & $\mathrm{C}_{6}-\mathrm{C}_{1}-\mathrm{C}_{11}-\mathrm{H}_{15}$ & -0.023 & - \\
\hline $\mathrm{C}_{1}-\mathrm{C}_{2}-\mathrm{C}_{3}-\mathrm{C}_{4}$ & 0.001 & $\mathrm{C}_{1}-\mathrm{C}_{2}-\mathrm{C}_{3}-\mathrm{C}_{4}$ & -0.012 & $\mathrm{C}_{1}-\mathrm{C}_{2}-\mathrm{C}_{3}-\mathrm{C}_{4}$ & -0.004 & - \\
\hline $\mathrm{C}_{1}-\mathrm{C}_{2}-\mathrm{C}_{3}-\mathrm{H}_{7}$ & -180.005 & $\mathrm{C}_{1}-\mathrm{C}_{2}-\mathrm{C}_{3}-\mathrm{H}_{7}$ & -180.020 & $\mathrm{C}_{1}-\mathrm{C}_{2}-\mathrm{C}_{3}-\mathrm{H}_{7}$ & -180.010 & - \\
\hline $\mathrm{Cl}_{9}-\mathrm{C}_{2}-\mathrm{C}_{3}-\mathrm{C}_{4}$ & 179.995 & $\mathrm{Cl}_{9}-\mathrm{C}_{2}-\mathrm{C}_{3}-\mathrm{C}_{4}$ & 180.005 & $\mathrm{Cl}_{9}-\mathrm{C}_{2}-\mathrm{C}_{3}-\mathrm{C}_{4}$ & 179.997 & - \\
\hline $\mathrm{H}_{7}-\mathrm{C}_{3}-\mathrm{C}_{4}-\mathrm{C}_{12}$ & 0.013 & $\mathrm{H}_{7}-\mathrm{C}_{3}-\mathrm{C}_{4}-\mathrm{C}_{12}$ & 0.011 & $\mathrm{H}_{7}-\mathrm{C}_{3}-\mathrm{C}_{4}-\mathrm{C}_{12}$ & 0.014 & - \\
\hline $\mathrm{C}_{3}-\mathrm{C}_{4}-\mathrm{C}_{5}-\mathrm{C}_{6}$ & 0.013 & $\mathrm{C}_{3}-\mathrm{C}_{4}-\mathrm{C}_{5}-\mathrm{C}_{6}$ & 0.025 & $\mathrm{C}_{3}-\mathrm{C}_{4}-\mathrm{C}_{5}-\mathrm{C}_{6}$ & 0.016 & - \\
\hline $\mathrm{C}_{3}-\mathrm{C}_{4}-\mathrm{C}_{5}-\mathrm{Cl}_{10}$ & -179.981 & $\mathrm{C}_{3}-\mathrm{C}_{4}-\mathrm{C}_{5}-\mathrm{Cl}_{10}$ & -179.990 & $\mathrm{C}_{3}-\mathrm{C}_{4}-\mathrm{C}_{5}-\mathrm{Cl}_{10}$ & -179.980 & - \\
\hline $\mathrm{C}_{12}-\mathrm{C}_{4}-\mathrm{C}_{5}-\mathrm{C}_{6}$ & 179.992 & $\mathrm{C}_{12}-\mathrm{C}_{4}-\mathrm{C}_{5}-\mathrm{C}_{6}$ & 180.009 & $\mathrm{C}_{12}-\mathrm{C}_{4}-\mathrm{C}_{5}-\mathrm{C}_{6}$ & 179.999 & - \\
\hline $\mathrm{C}_{12}-\mathrm{C}_{4}-\mathrm{C}_{5}-\mathrm{Cl}_{10}$ & -0.003 & $\mathrm{C}_{12}-\mathrm{C}_{4}-\mathrm{C}_{5}-\mathrm{Cl}_{10}$ & -0.008 & $\mathrm{C}_{12}-\mathrm{C}_{4}-\mathrm{C}_{5}-\mathrm{Cl}_{10}$ & -0.001 & - \\
\hline $\mathrm{C}_{12}-\mathrm{C}_{4}-\mathrm{C}_{5}-\mathrm{H}_{16}$ & -120.502 & $\mathrm{C}_{12}-\mathrm{C}_{4}-\mathrm{C}_{5}-\mathrm{H}_{16}$ & -120.440 & $\mathrm{C}_{12}-\mathrm{C}_{4}-\mathrm{C}_{5}-\mathrm{H}_{16}$ & -120.350 & - \\
\hline $\mathrm{C}_{3}-\mathrm{C}_{4}-\mathrm{C}_{12}-\mathrm{H}_{17}$ & -0.016 & $\mathrm{C}_{3}-\mathrm{C}_{4}-\mathrm{C}_{12}-\mathrm{H}_{17}$ & -0.014 & $\mathrm{C}_{3}-\mathrm{C}_{4}-\mathrm{C}_{12}-\mathrm{H}_{17}$ & -0.023 & - \\
\hline $\mathrm{C}_{3}-\mathrm{C}_{4}-\mathrm{C}_{12}-\mathrm{H}_{18}$ & 120.459 & $\mathrm{C}_{3}-\mathrm{C}_{4}-\mathrm{C}_{12}-\mathrm{H}_{18}$ & 120.405 & $\mathrm{C}_{3}-\mathrm{C}_{4}-\mathrm{C}_{12}-\mathrm{H}_{18}$ & 120.295 & - \\
\hline $\mathrm{C}_{5}-\mathrm{C}_{4}-\mathrm{C}_{12}-\mathrm{H}_{16}$ & 59.520 & $\mathrm{C}_{5}-\mathrm{C}_{4}-\mathrm{C}_{12}-\mathrm{H}_{16}$ & 59.575 & $\mathrm{C}_{5}-\mathrm{C}_{4}-\mathrm{C}_{12}-\mathrm{H}_{16}$ & 59.665 & - \\
\hline $\mathrm{C}_{5}-\mathrm{C}_{4}-\mathrm{C}_{12}-\mathrm{H}_{17}$ & -179.993 & $\mathrm{C}_{5}-\mathrm{C}_{4}-\mathrm{C}_{12}-\mathrm{H}_{17}$ & -180.000 & $\mathrm{C}_{5}-\mathrm{C}_{4}-\mathrm{C}_{12}-\mathrm{H}_{17}$ & -180.010 & - \\
\hline $\mathrm{C}_{5}-\mathrm{C}_{4}-\mathrm{C}_{12}-\mathrm{H}_{18}$ & -59.519 & $\mathrm{C}_{5}-\mathrm{C}_{4}-\mathrm{C}_{12}-\mathrm{H}_{18}$ & -59.577 & $\mathrm{C}_{5}-\mathrm{C}_{4}-\mathrm{C}_{12}-\mathrm{H}_{18}$ & -59.687 & - \\
\hline $\mathrm{C}_{4}-\mathrm{C}_{5}-\mathrm{C}_{6}-\mathrm{C}_{1}$ & 0.001 & $\mathrm{C}_{4}-\mathrm{C}_{5}-\mathrm{C}_{6}-\mathrm{C}_{1}$ & -0.012 & $\mathrm{C}_{4}-\mathrm{C}_{5}-\mathrm{C}_{6}-\mathrm{C}_{1}$ & -0.004 & - \\
\hline
\end{tabular}

substitutions of halogens and methyl groups in para position. The calculated bond lengths for $\mathrm{C}_{1}-\mathrm{C}_{12} \& \mathrm{C}_{4}-\mathrm{C}_{12}$ of about $1.51 \AA$, the methyl $\mathrm{C}-\mathrm{H}$ in the range 1.09-1.10 $\AA$ and ring $\mathrm{C}-\mathrm{H}$ as $1.08 \AA$ are correlated well with the standard values. But, the bond length of $\mathrm{C}-\mathrm{Cl}$ observed as $1.83 \AA$ is higher than the standard values..$^{21,22}$

In addition, $\mathrm{C}_{2}-\mathrm{C}_{3}-\mathrm{C}_{4}, \mathrm{C}_{1}-\mathrm{C}_{6}-\mathrm{C}_{5}\left(119.3^{\circ}\right), \mathrm{C}_{2}-\mathrm{C}_{1}-\mathrm{C}_{6} \& \mathrm{C}_{3}-\mathrm{C}_{4}-$ $\mathrm{C}_{5}\left(117.1^{\circ}\right)$ bond angles are reduced than that of a benzene ring, but the $\mathrm{C}_{1}-\mathrm{C}_{2}-\mathrm{C}_{3}\left(121.6^{\circ}\right)$ bond angle is enlarged. The dihedral angles obtained are represented in Table 1 . From the Table, it can be seen that, the dihedral angels $\mathrm{C}_{6}-\mathrm{C}_{1}-\mathrm{C}_{2}-\mathrm{C}_{3}, \mathrm{C}_{2}-\mathrm{C}_{1}-\mathrm{C}_{6}-\mathrm{C}_{5}$ and $\mathrm{C}_{1}-\mathrm{C}_{2}-\mathrm{C}_{3}-\mathrm{C}_{4}$ are supported the planer nature of aromatic ring. The optimization geometry of DCPX showed that, two substituted methyl groups are out-of-plane of the ring. ${ }^{20-22}$ This has been evidenced from the dihedral angels of $\mathrm{C}_{2}-\mathrm{C}_{1}-\mathrm{C}_{11}-\mathrm{H}_{14} \approx 60^{\circ}, \mathrm{C}_{6}-$ $\mathrm{C}_{1}-\mathrm{C}_{11}-\mathrm{H}_{13} \approx 120^{\circ}$ and $\mathrm{C}_{5}-\mathrm{C}_{4}-\mathrm{C}_{12}-\mathrm{H}_{16} \approx 60^{\circ}, \mathrm{C}_{3}-\mathrm{C}_{4}-\mathrm{C}_{12}-\mathrm{H}_{18} \approx$ $120^{\circ}$. Similarly other two $\mathrm{C}_{11}-\mathrm{H}_{15}$ and $\mathrm{C}_{12}-\mathrm{H}_{17}$ are in-planebending of ring which has been known from the following dihedral angles $\mathrm{C}_{6}-\mathrm{C}_{1}-\mathrm{C}_{11}-\mathrm{H}_{15} \approx 0^{\circ}$ and $\mathrm{C}_{3}-\mathrm{C}_{4}-\mathrm{C}_{12}-\mathrm{H}_{17} \approx 0^{\circ}$.

\subsection{Assignments of spectra}

Normal coordinate analysis provides a detailed description of vibrational modes. For this purpose, the full set of 62 standard internal coordinates containing 14 redundancies have been calculated and listed in Table S2 of ESI. $\uparrow$ From these, a nonredundant set of local symmetry coordinates was constructed by appropriate linear combinations of internal coordinates according to Pulay et al. $^{23}$ and they are presented in Table S3 of ESI. $\dagger$ DFT force fields calculated theoretically have been transformed as a set of vibrational coordinates and then used for all subsequent calculations. The fundamental modes of DCPX in terms of vibrational assignments associated with theoretical IR, Raman intensities and normal mode descriptions (characterized by PED) are listed in Table 2 .

When using computational methods to predict theoretical normal vibrations for relatively complex polyatomic molecules, scaling strategies are used to bring computed wave numbers. The observed FT-IR and FT-Raman spectra of the DCPX were presented in Fig. 2 and 3. The 48 normal modes of DCPX are distributed among the symmetry species as $\Gamma_{3 \mathrm{~N}-6}=33 \mathrm{~A}^{\prime}$ (inplane) $+15 \mathrm{~A}^{\prime \prime}$ (out-of-plane). The detailed vibrational assignments of fundamental modes of DCPX have been reported in Table S3. $\dagger$ Root mean square (RMS) values of frequencies were obtained in the study using the following expression,

$$
\mathrm{RMS}=\sqrt{\frac{1}{n-1} \sum_{i}^{n}\left(U_{i}^{\mathrm{calc}}-U_{i}^{\exp }\right)^{2}}
$$


The RMS frequency error is being $101 \mathrm{~cm}^{-1}$. Earlier report revealed that other methods than B3LYP such as HF showed more deviation in experimental and calculated values for substituted xylene derivative. Hence, B3LYP method has been adopted in the present study to calculate vibrational frequencies for DCPX according to Govindarajan et al. ${ }^{11}$ Systematic assignment is produced using the unscaled computed frequencies. Then for comparing the theoretical values, with the calculated frequencies, they were multiplied by a common scale factor of less than one to reduce the overall deviation. Pulay ${ }^{24}$ recommended a set of transferable coordinates to refine the scale factors. The least square refinement of the scale factors led to a mean deviation of $7.09 \mathrm{~cm}^{-1}$ for DCPX. The least square refinement of results relies on the frequencies observed and on the initial band assignments. The uniform scaling force field does not change the nature of calculated intensity patterns of simulated spectra, because it does not changes the vibrational modes. The selective scaling changes the frequencies in addition to changing the normal modes of vibrations. The changes in relative band intensities were caused by the changes in PED values which are corresponding to vibrational vectors.

4.2.1. C-H vibrations. Regularly the bands in the range $3300-3000 \mathrm{~cm}^{-1}$ are assigned to $\mathrm{C}-\mathrm{H}$ stretching vibrations of aromatic compounds. ${ }^{25}$ The $\mathrm{C}-\mathrm{H}$ vibrations of the DCPX are observed at $3249 \mathrm{~cm}^{-1}$ in FT-IR spectrum and $3239 \mathrm{~cm}^{-1}$ in FTRaman. The bands at $3245 \mathrm{~cm}^{-1}$ in FT-IR and $3235 \mathrm{~cm}^{-1}$ in FTRaman from B3LYP/6-311G** method is in good agreement with observed spectral data. These are intense stretching modes and identified from the PED in Table 2. The $\mathrm{C}-\mathrm{H}$ in-plane bending vibrations, generally occurs in 1000-1300 $\mathrm{cm}^{-1}$ region. ${ }^{25-28}$ The FT-IR bands observed at $1225 \mathrm{~cm}^{-1}$ are assigned to $\mathrm{C}-\mathrm{H}$ in-plane-bending vibration, which was arrived in FTRaman spectra at $1262 \mathrm{~cm}^{-1}$ are assigned to $\mathrm{C}-\mathrm{H}$ in-planebending vibrations. The bands at $1221 \mathrm{~cm}^{-1}$ in FT-IR and $1257 \mathrm{~cm}^{-1}$ in FT-Raman are in good agreement with observed spectral data. The $\mathrm{C}-\mathrm{H}$ out-of-plane bending vibrational frequencies are mainly identified by the number of adjacent hydrogen atoms on the ring and not vastly affected by the nature of substitutions.

The C-H out-of-plane bending vibrations which are strongly coupled vibrations usually occurred in the region 1000-750 $\mathrm{cm}^{-1} \cdot{ }^{28,29}$ For DCPX, the strong bands in experimental FT-IR spectrum at $881 \mathrm{~cm}^{-1}(80 \%)$ suggested the existence of aromatic $\mathrm{C}-\mathrm{H}$ out-of-plane bending vibrations and very strong band in experimental FT-Raman spectrum at $895 \mathrm{~cm}^{-1}(84 \%)$ confirmed the presence of aromatic $\mathrm{C}-\mathrm{H}$ out-of-plane bending vibrations which are well correlated $\left(885 \mathrm{~cm}^{-1}\right.$ and $\left.890 \mathrm{~cm}^{-1}\right)$ with calculated vibrational spectra using B3LYP/6-311G** methods. The observation of smaller deviation of calculated vibrational frequencies with experimental vibrational frequencies validated the adoption of the above said functional in the present study. The theoretically computed frequencies are presented in Table 2.

4.2.2. C-C vibrations. The ring $\mathrm{C}-\mathrm{C}$ and ring $\mathrm{C}=\mathrm{C}$ stretching vibrations (semicircle stretching region) are generally appears in the region $1625-1400 \mathrm{~cm}^{-1}$ and $1380-1280 \mathrm{~cm}^{-1},{ }^{28-31}$ respectively. The ring stretching vibrations are expected within the region $1620-1390 \mathrm{~cm}^{-1}$. In the present study, the absorption at 1605, 1526, 1401, $1262 \mathrm{~cm}^{-1}$ (FT-Raman), 1447, 1334, 1225 $\mathrm{cm}^{-1}$ (FT-IR) are assigned to C-C stretching vibrations. The FTIR bands observed at 725 and $530 \mathrm{~cm}^{-1}$ and FT-Raman at 776 and $352 \mathrm{~cm}^{-1}$ are assigned to $\mathrm{C}-\mathrm{C}$ in-plane and out-of-plane bending vibrations, respectively. These assignments are in quite agreement with the literature and in addition the nature and position of the substitution affected the band in this region. ${ }^{30,31}$ Aromatic ring vibrational modes are pretentious by the substitution in the aromatic ring.

4.2.3. C-Cl vibrations. The vibrations due to $\mathrm{C}-\mathrm{X}(\mathrm{X}=\mathrm{F}, \mathrm{Cl}$ etc.) bonds formed between the ring and the halogen atoms, are quite informative since mixing of vibrations are possible due to the lowering of molecular symmetry and the presence of heavy atoms. ${ }^{31-33}$ The $\mathrm{C}-\mathrm{Cl}$ stretching frequency is generally observed in the region $800-500 \mathrm{~cm}^{-1}$ which is depending on the configuration and conformation of the compound. Regarding the above information the following absorption bands in both FTIR and FT-Raman spectra arose at $726,479 \mathrm{~cm}^{-1}$ and 775 $\mathrm{cm}^{-1}$ respectively were corresponded to planar $\mathrm{C}-\mathrm{Cl}$ stretching of DCPX. The planar $\mathrm{C}-\mathrm{Cl}$ bending modes appeared to be relatively pure. In addition, the $\mathrm{C}-\mathrm{Cl}$ out-of-plane bending vibrations were appeared at 530, $479 \mathrm{~cm}^{-1}$ and 352, 295, 243 $\mathrm{cm}^{-1}$ in FT-IR and FT-Raman, respectively. There is a very slight deviation in both the in-plane and out-of-plane vibrations of DCPX have been observed. After scaling of computed values for $\mathrm{C}-\mathrm{Cl}$ in-plane and out-of-plane bending vibrations by B3LYP/6$311 \mathrm{G}^{* *}$ functional, those slight deviations have also been reduced. The observation further supported the validation of same functional in the present study. ${ }^{30-33}$

4.2.4. Methyl group vibrations. In DCPX, there are $\mathrm{CH}_{3}$ groups substituted in first and fourth position aromatic ring. Regarding vibrational frequencies of $\mathrm{CH}_{3}$, there is a possibility of the symmetrical ( $\left.\mathrm{CH}_{3} \mathrm{ips}\right)$ and asymmetrical ( $\left.\mathrm{CH}_{3} \mathrm{ops}\right)$, in-plane stretching modes (i.e. in-plane hydrogen stretching mode); deformation of symmetrical $\left(\mathrm{CH}_{3} \mathrm{ss}\right)$, and asymmetrical $\left(\mathrm{CH}_{3}\right.$ ips), the in-plane $\left(\mathrm{CH}_{3} \mathrm{ipr}\right)$, out-of-plane $\left(\mathrm{CH}_{3} \mathrm{opr}\right)$ rocking and twisting $\left(\mathrm{t} \mathrm{CH}_{3}\right)$ modes. ${ }^{11-13,31}$ Further, the asymmetric stretching $\left(\mathrm{CH}_{3}\right.$ ops $)$ and asymmetric deformation $\left(\mathrm{CH}_{3} \mathrm{opb}\right)$ of $\mathrm{CH}_{3}$ group are assumed to be depolarized for $\mathrm{A}^{\prime \prime}$ symmetry species. The asymmetric stretch is generally appeared as higher wave number than the symmetric stretch. The bands at 3160 ips, 3114 ops, $3054 \mathrm{ss} \mathrm{cm}^{-1}$ in FT-IR and $3158 \mathrm{ips,} 3061 \mathrm{ops} \mathrm{cm}^{-1}$ in FT-Raman spectra are assigned to $\mathrm{C}-\mathrm{H}$ asymmetric stretching vibration. We have observed the symmetrical methyl deformation mode at 1447 $\mathrm{cm}^{-1}$ in FT-IR and at $1401 \mathrm{~cm}^{-1}$ in FT-Raman. The absorptions appeared at 1078, $1067 \mathrm{~cm}^{-1}$ in FT-IR and 1081, $1065 \mathrm{~cm}^{-1}$ in FTRaman are rocking vibrations of $\mathrm{CH}_{3}$, respectively. Further, the out-of-plane bending vibrations of methyl groups are assigned at $165 \mathrm{~cm}^{-1}$ FT-Raman. ${ }^{11-13}$ The fundamental vibrations, for all the modes of $\mathrm{CH}_{3}$ group of DCPX are observed in their respective characteristic regions and they are listed in Table 2.

\subsection{NMR}

The isotropic chemical shifts are normally used to identify the organic reactive sites. It is important to predict exact molecular 
Table 2 Vibrational assignments of experimental frequencies of DCPX along with calculated frequencies by B3LYP/6-311G** functional ${ }^{a}$

\begin{tabular}{|c|c|c|c|c|c|c|c|c|}
\hline \multirow[b]{2}{*}{ S. no. } & \multirow{2}{*}{$\begin{array}{l}\text { Symmetry of } \\
\text { species } C_{\mathrm{s}}\end{array}$} & \multicolumn{2}{|c|}{$\begin{array}{l}\text { Observed frequency } \\
\left(\mathrm{cm}^{-1}\right)\end{array}$} & \multicolumn{4}{|c|}{$\begin{array}{l}\text { Calculated frequency }\left(\mathrm{cm}^{-1}\right) \text { with B3LYP/6- } \\
311 \mathrm{G}^{* *} \text { force field }\end{array}$} & \multirow{2}{*}{$\begin{array}{l}\text { PED (\%) among type of internal } \\
\text { coordinates }^{d}\end{array}$} \\
\hline & & Infrared & Raman & Unscaled & Scaled & $\operatorname{IR}^{b} A_{\mathrm{i}}$ & $\operatorname{Raman}^{c} I_{\mathrm{i}}$ & \\
\hline 1 & $\mathrm{~A}^{\prime}$ & 3249 & & 3247 & 3245 & 14.762 & 63.175 & vCH (99) \\
\hline 2 & $\mathrm{~A}^{\prime}$ & & 3239 & 3237 & 3235 & 14.611 & 64.334 & $v \mathrm{CH}(99)$ \\
\hline 3 & $\mathrm{~A}^{\prime}$ & 3160 & & 3159 & 3157 & 0.004 & 152.4 & $\mathrm{CH}_{3}$ ips (98) \\
\hline 4 & $\mathrm{~A}^{\prime}$ & & 3158 & 3159 & 3155 & 4.946 & 0.094 & $\mathrm{CH}_{3}$ ips (98) \\
\hline 5 & $\mathrm{~A}^{\prime}$ & & & 3115 & 3111 & 16.428 & 185.539 & $\mathrm{CH}_{3}$ ops (96) \\
\hline 6 & $\mathrm{~A}^{\prime}$ & 3114 & & 3113 & 3110 & 20.01 & 152.897 & $\mathrm{CH}_{3}$ ops (96) \\
\hline 7 & $\mathrm{~A}^{\prime}$ & & 3061 & 3060 & 3056 & 12.537 & 73.311 & $\mathrm{CH}_{3}$ ops (96) \\
\hline 8 & $\mathrm{~A}^{\prime}$ & 3057 & & 3058 & 3055 & 9.822 & 93.552 & $v \mathrm{CH}_{3}(96)$ \\
\hline 9 & $\mathrm{~A}^{\prime}$ & & & 1656 & 1653 & 0 & 42.075 & vCC (67), bCH (12), bring (11) \\
\hline 10 & $\mathrm{~A}^{\prime}$ & & 1605 & 1602 & 1601 & 0.008 & 23.423 & $\nu \mathrm{CC}(53), \gamma \mathrm{CH}_{3}(15)$, bring (8), $\beta \mathrm{CH}_{3}$ (11) \\
\hline 11 & $\mathrm{~A}^{\prime}$ & 1535 & & 1532 & 1530 & 46.449 & 1.068 & $\gamma \mathrm{CH}_{3}(49), \beta_{\mathrm{CH}}(45)$ \\
\hline 12 & $\mathrm{~A}^{\prime}$ & & 1526 & 1524 & 1521 & 44.231 & 0.632 & $v \mathrm{CC}(33), \mathrm{bCH}(22), \beta \mathrm{CH}_{3}(17), \gamma \mathrm{CH}_{3}(19)$ \\
\hline 13 & $\mathrm{~A}^{\prime}$ & & & 1521 & 1518 & 2.961 & 20.565 & $\beta_{\mathrm{CH}_{3}}(37), \gamma \mathrm{CH}_{3}(49), \mathrm{CCH}_{3}(18)$ \\
\hline 14 & $\mathrm{~A}^{\prime}$ & 1515 & & 1517 & 1514 & 8.508 & 14.364 & $\beta \mathrm{CH}_{3}(91),\left(\mathrm{CH}_{3}\right) \mathrm{r}(5)$ \\
\hline 15 & $\mathrm{~A}^{\prime}$ & & 1510 & 1509 & 1506 & 3.936 & 17.38 & $\gamma \mathrm{CH}_{3}(72), \mathrm{\beta CH}_{3}(22)$ \\
\hline 16 & $\mathrm{~A}^{\prime}$ & & & 1451 & 1448 & 0.41 & 22.795 & $\gamma \mathrm{CH}_{3}(79), \nu \mathrm{CC}(7), \beta_{\mathrm{CH}_{3}}(5)$ \\
\hline 17 & $\mathrm{~A}^{\prime}$ & 1447 & & 1449 & 1446 & 0.271 & 30.536 & $\gamma \mathrm{CH}_{3}(79), v \mathrm{CC}(7), \beta_{\mathrm{CH}}(5)$ \\
\hline 18 & $\mathrm{~A}^{\prime}$ & & 1401 & 1399 & 1397 & 22.045 & 0.011 & $v \mathrm{CC}(38), \gamma \mathrm{CH}_{3}(12), \beta_{\mathrm{CH}}(15)$ \\
\hline 19 & $\mathrm{~A}^{\prime}$ & 1334 & & 1332 & 1329 & 2.69 & 0.004 & vCC $(84)$ \\
\hline 20 & $\mathrm{~A}^{\prime}$ & & & 1295 & 1294 & 0.015 & 0.098 & bCH (72), vCC (9) \\
\hline 21 & $\mathrm{~A}^{\prime}$ & & 1262 & 1261 & 1257 & 0 & 26.44 & $\gamma \mathrm{CH}(49), v \mathrm{CC}(42), \mathrm{CCl}(7)$ \\
\hline 22 & $\mathrm{~A}^{\prime}$ & 1225 & & 1223 & 1221 & 1.6 & 0 & $\gamma \mathrm{CH}(37), v \mathrm{CC}(42)$, bring (15) \\
\hline 23 & $\mathrm{~A}^{\prime}$ & & & 1092 & 1089 & 123.645 & 0 & bring (46), vCCl (20), vCC (17), bCH (10) \\
\hline 24 & $\mathrm{~A}^{\prime \prime}$ & & 1081 & 1080 & 1078 & 5.982 & 0.113 & $\mathrm{gCC}(60), \mathrm{CH}_{3} \mathrm{r}(23), \mathrm{gCH}(5), \beta_{\mathrm{CH}_{3}}(5)$ \\
\hline 25 & $\mathrm{~A}^{\prime \prime}$ & 1078 & & 1075 & 1070 & 0.706 & 1.022 & gCC (57), $\mathrm{CH}_{3} \mathrm{r}(24)$, tring $(8)$ \\
\hline 26 & $\mathrm{~A}^{\prime}$ & 1067 & 1065 & 1062 & 1059 & 1.492 & 2.605 & $\mathrm{CH}_{3} \mathrm{r}(56), \gamma \mathrm{CH}_{3}(13), \beta \mathrm{CH}_{3}(9), v \mathrm{CC}(7)$ \\
\hline 27 & $\mathrm{~A}^{\prime}$ & & & 1024 & 1020 & 26.262 & 0.204 & $\mathrm{CH}_{3} \mathrm{r}(45), \gamma \mathrm{CC}(17), \gamma \mathrm{CH}_{3}(11), \beta \mathrm{CH}_{3}(8)$ \\
\hline 28 & $\mathrm{~A}^{\prime \prime}$ & 954 & & 952 & 949 & 0.001 & 5.648 & $\operatorname{gCCl}(34)$, vCC (24), bring (23), vCC (16) \\
\hline 29 & $\mathrm{~A}^{\prime \prime}$ & & 895 & 893 & 890 & 19.957 & 0.001 & $\beta \mathrm{CH}(84)$, tring $(8)$ \\
\hline 30 & $\mathrm{~A}^{\prime \prime}$ & 881 & & 887 & 885 & 0.008 & 3.534 & $\beta \mathrm{CH}(80)$, tring $(14)$ \\
\hline 31 & $\mathrm{~A}^{\prime}$ & & 775 & 776 & 774 & 26.255 & 0 & $\gamma \mathrm{CC}(57)$, bring (21), vCCl (13) \\
\hline 32 & $\mathrm{~A}^{\prime}$ & 726 & & 725 & 721 & 0 & 16.305 & bring (58), $\gamma \mathrm{CC}(19), v \mathrm{CCl}(15)$ \\
\hline 33 & $\mathrm{~A}^{\prime \prime}$ & & & 704 & 702 & 0 & 0.525 & tring (62), gCCl (20), gCC (15) \\
\hline 34 & $\mathrm{~A}^{\prime \prime}$ & & 605 & 603 & 600 & 0.161 & 0 & tring (35), gCCl (34), gCC (27) \\
\hline 35 & $\mathrm{~A}^{\prime \prime}$ & & & 536 & 534 & 24.613 & 0 & gCCl (67), bring (14) \\
\hline 36 & $\mathrm{~A}^{\prime}$ & 530 & & 528 & 525 & 0 & 5.872 & $\beta \mathrm{CC}(46), \mathrm{bCC}(23), \beta \mathrm{CCl}(38)$ \\
\hline 37 & $\mathrm{~A}^{\prime}$ & 479 & & 478 & 474 & 0 & 9.65 & bring (52), $\beta \mathrm{CCl}(7)$ \\
\hline 38 & $\mathrm{~A}^{\prime \prime}$ & & & 461 & 458 & 3.958 & 0 & tring (61), gCCl (19), gCC (16) \\
\hline 39 & $\mathrm{~A}^{\prime \prime}$ & & 352 & 350 & 348 & 0 & 1.355 & $\beta C C(47), \beta C C l(47)$ \\
\hline 40 & $\mathrm{~A}^{\prime}$ & & & 331 & 328 & 0 & 9.239 & bring (45), vCCl (43) \\
\hline 41 & $\mathrm{~A}^{\prime}$ & & 295 & 294 & 290 & 3.36 & 0 & $\beta C C l(41), \operatorname{bCCl}(10)$ \\
\hline 42 & $\mathrm{~A}^{\prime \prime}$ & & & 246 & 244 & 0 & 2.35 & tring (31), gCCl (26), gCC (20), gCH (12) \\
\hline 43 & $\mathrm{~A}^{\prime}$ & & 243 & 241 & 240 & 0 & 1.604 & bCCl (28), $\beta$ CC1 (32), bring (9) \\
\hline 44 & $\mathrm{~A}^{\prime}$ & & & 225 & 220 & 1.339 & 0 & $\mathrm{bCCl}_{1}(45)$ \\
\hline 45 & $\mathrm{~A}^{\prime \prime}$ & & 165 & 167 & 164 & 0.132 & 0 & $\begin{array}{l}\beta_{\mathrm{CH}}(40), \mathrm{gCCl}(20) \text {, tring (16), gCH (11), } \\
\text { gCC (10) }\end{array}$ \\
\hline 46 & $\mathrm{~A}^{\prime \prime}$ & & 153 & 151 & 147 & 0.001 & 0.568 & $\mathrm{tCH}_{3}(56), \mathrm{gCC}(7)$ \\
\hline 47 & $\mathrm{~A}^{\prime \prime}$ & & & 139 & 137 & 1.009 & 0 & $\begin{array}{l}\mathrm{tCH}_{3}(6), \text { gCC (20), tring (17), } \mathrm{tCH}_{3}(16), \\
\operatorname{gCCl}(9), \mathrm{gCH}(8)\end{array}$ \\
\hline 48 & $\mathrm{~A}^{\prime \prime}$ & & & 90 & 88 & 1.352 & 0 & tring $(90)$ \\
\hline
\end{tabular}

${ }^{a}$ Abbreviations: $v$ - stretching, $\mathrm{b}$ - bending, $\gamma$ - in-plane bending, $\beta$ - out-of-plane bending, $\mathrm{t}$ - torsion, $\mathrm{r}$ - rocking, $\mathrm{g}$ - waging, ips - in-plane stretching, ops - out-of-plane stretching. ${ }^{b}$ Relative absorption intensities normalized with highest peak absorption. ${ }^{c}$ Relative Raman intensities calculated by eqn (1) and normalized to $100 .{ }^{d}$ For the notations used see Table S3.

geometries in order to calculate the magnetic properties of molecules. ${ }^{12,34}$ Hence, complete optimized geometry of DCPX was performed using TMS B3LYP/6-311+G (2d, p) and TMS HF/ 6-31G (d) GIAO methods in order to get better understanding in the structural features of the title compound. ${ }^{16}$ The ${ }^{1} \mathrm{H}$ and ${ }^{13} \mathrm{C}$ NMR chemical shift values of the DCPX have been calculated by Gauge Invariant Atomic Orbital (GIAO) method. ${ }^{12,35,36}$ The experimental and theoretical chemical shift values for ${ }^{1} \mathrm{H}$ and 
${ }^{13} \mathrm{C}$ NMR of DCPX are given in Table 3. The theoretical and experimental NMR spectra include ${ }^{1} \mathrm{H} \&{ }^{13} \mathrm{C}$ for DCPX is given in Fig. S1 (ESI), $\dagger$ where TMS has been used as a reference. The theoretically calculated and experimentally observed chemical shifts values of DCPX in both ${ }^{1} \mathrm{H} \&{ }^{13} \mathrm{C}$ NMR are reliably in good agreement with each other. Ring carbons had greater chemical shift values than the aliphatic carbons, due to the influence of the resonance effect of the aromatic ring. ${ }^{33}$ Further, the poor electron donating nature $(+I$ effect) of methyl group increased the chemical shift of the ring carbon $\left(\mathrm{C}_{1}\right.$ and $\left.\mathrm{C}_{4}\right)$. The chlorine substituted carbon atoms have greater chemical shift than all other carbons of DCPX. This could be attributed to the electro negativity of chlorine atoms. The signals of the aromatic proton $\left(\mathrm{H}_{7} \& \mathrm{H}_{8}\right)$ were observed at $5.8 \mathrm{ppm}$. The $\mathrm{H}$ atom is the smallest of all atoms and mostly localized on the periphery of molecules. The methyl group protons showed less chemical shift values than the aromatic ring protons. The ring protons involved in the delocalization of $\pi$ electrons in the benzene ring. Among the methyl protons, of $\mathrm{H}_{16}$ and $\mathrm{H}_{14}$ have higher chemical shift values as they might be involved in the intra molecular hydrogen bonding $\left(\mathrm{H}_{14}-\mathrm{Cl}\right.$ and $\left.\mathrm{H}_{16}-\mathrm{Cl}\right){ }^{37-41}$

\subsection{Natural bond orbital (NBO) analysis}

Natural bond orbital (NBO) analysis gives the information about nature of hydrogen bonding and interaction among bonds, and also gives information about transfer or conjugative interactions of molecular systems..$^{25,35,36}$ In addition, it gives essential information on the interactions of donor and accepter orbitals of molecules which enable the assessment of intra and intermolecular interactions. This is carried out by considering all possible interactions between filled and empty NBOs and calculating their energy importance by second order perturbation theory. For each electron donor (i) and electron acceptor (j), the stabilization energy $\left(E^{2}\right)$ associates with electron delocalization between Lewis (filled) and non Lewis (unfilled) is estimated as:

$$
E^{(2)}=-q_{\mathrm{i}} \frac{\left(F_{\mathrm{i}, \mathrm{j}}\right)^{2}}{\varepsilon_{\mathrm{j}}-\varepsilon_{\mathrm{i}}}
$$

where, $q_{\mathrm{i}}, \varepsilon_{\mathrm{i}} \& \varepsilon_{\mathrm{j}}$ are donor orbital occupancy, diagonal elements, orbital energies, respectively. $F(\mathrm{i}, \mathrm{j})$ is the off diagonal NBO Fock matrix element. Larger the stabilization energy $E_{\mathrm{j}}^{(2)}$ value the higher is the interaction between electron filled (donor) and unfilled (acceptor) orbital's i.e., greater the donating ability from donors to acceptor cause the greater extent of conjugation of the whole system. The Lewis structure of occupied orbitals can interact strongly. ${ }^{12,41,42}$ A filled bonding orbital can act as a donor and an unfilled antibonding can act as an acceptor. Delocalization of electron density between filled Lewis (bond or lone pair) NBO orbital and unfilled non Lewis (antibond or Rydberg) NBO orbital corresponds to a stabilizing donoracceptor interaction.

NBO analysis has been calculated at the DFT/B3LYP/6$311 \mathrm{G}^{* *}$ functional in order to clarify the charge transfer or conjugative interaction, the intra compound rehybridization and delocalization of electron density within the molecule. The second-order perturbation theory of Fock matrix in the NBO of the DCPX showed the presence of strong intramolecular hyperconjugative interactions which are listed in Table 4. In NBO analysis of DCPX, we had observed two types of halogen $\left(\mathrm{Cl}_{9} \& \mathrm{Cl}_{10}\right)$ antibonding with their respective stabilization energies. They were observed as follows $\mathrm{Cl}_{9}$ (LP1) undergoes $\pi^{*} \mathrm{C} 2-\mathrm{C} 3, \sigma^{*} \mathrm{C} 1-\mathrm{C} 2$ interaction with $E^{(2)}$ of $12.45,11.68 \mathrm{~kJ} \mathrm{~mol}^{-1}$ where as $\mathrm{Cl}_{10}$ (LP1) $\sigma^{*} \mathrm{C} 5-\mathrm{C} 6, \pi^{*} \mathrm{C} 4-\mathrm{C} 5$ resulted the stabilization energy $E^{(2)}$ of $11.24,12.19 \mathrm{~kJ} \mathrm{~mol}^{-1}$, respectively. This stronger interaction around the ring could enhance the bioactivity of DCPX. The $p$-character of chlorine lone pair contributes the electron donating ability of DCPX.

\subsection{Mulliken population analysis}

Mulliken Population Analysis (MPA) of Mulliken atomic charge (MAC) is a significant tool which analyzes the electronic properties of a particular molecule. ${ }^{43}$ Further, it helps in the determination of atomic charges, dipole moment, molecular polarizability and electronic structure of a molecule. The total atomic charges of DCPX were obtained by Mulliken population analysis with B3LYP/6-311G** functional (Fig. 4). The negative

(a)

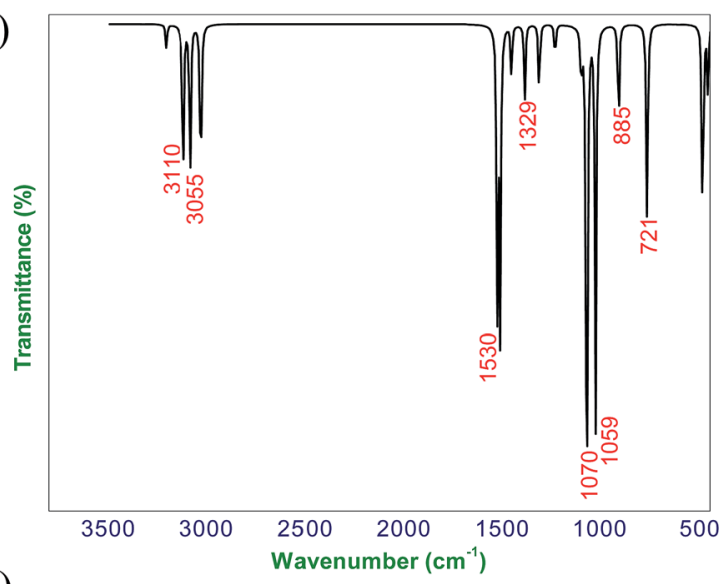

(b)

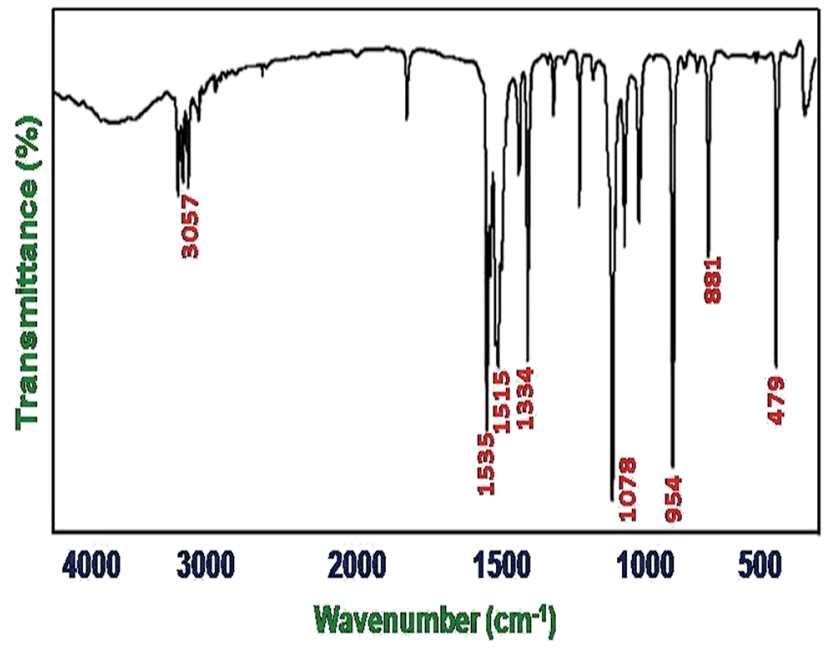

Fig. 2 (a) Calculated (B3LYP/6-311G**) FT-IR spectra of DCPX, (b) observed FT-IR spectra of DCPX. 
values of $\mathrm{C}_{2}, \mathrm{C}_{3}, \mathrm{C}_{5}, \mathrm{C}_{6}, \mathrm{C}_{11}, \mathrm{C}_{12}, \mathrm{Cl}_{9}$ and $\mathrm{Cl}_{10}$ in the aromatic ring indicated the redistribution of electron density (Table $\mathrm{S} 4$ in ESI $\dagger$ ). Due to these strong negative charges $\mathrm{C}_{2}$ and $\mathrm{C}_{5}$ accommodated higher positive charge and become more acidic. The substitution of halogen implied negative values on ring carbons where as the methyl group's substitution kept $\mathrm{C}_{4}$ of aromatic ring as positive.

\subsection{Molecular electrostatic potential (MEP)}

MEP is an extensive analytical tool for the description of noncovalent interactions particularly hydrogen bonds. MEP analysis enables the identification of high susceptible interactive centre with a proton in the surrounding space of a molecule. $^{\mathbf{1 2 , 4 0 , 4 4}}$ This can be used to predict potential interactions between the molecule and a particular host. To predict the reactive sites of electrophilic and nucleophilic attack for the investigated molecule, MEP at the B3LYP/6-311G** optimized geometry was drawn (Fig. S2 in ESI $\dagger$ ). From Fig. S2 (ESI $\dagger$ ) negative (red and orange) area of the MEP are relative to the electrophilic reactivity and the positive blue area are related to nucleophilic reactivity. From the MEP map of the DCPX molecule, it is clear that negative potential are on the electronegative halogen atoms $\left(\mathrm{Cl}_{9} \& \mathrm{Cl}_{10}\right)$, where as the regions having the positive potential are over the hydrogen atoms. Blue color (Fig. S2 of ESI $\dagger$ ) indicates the strongest attraction and a red

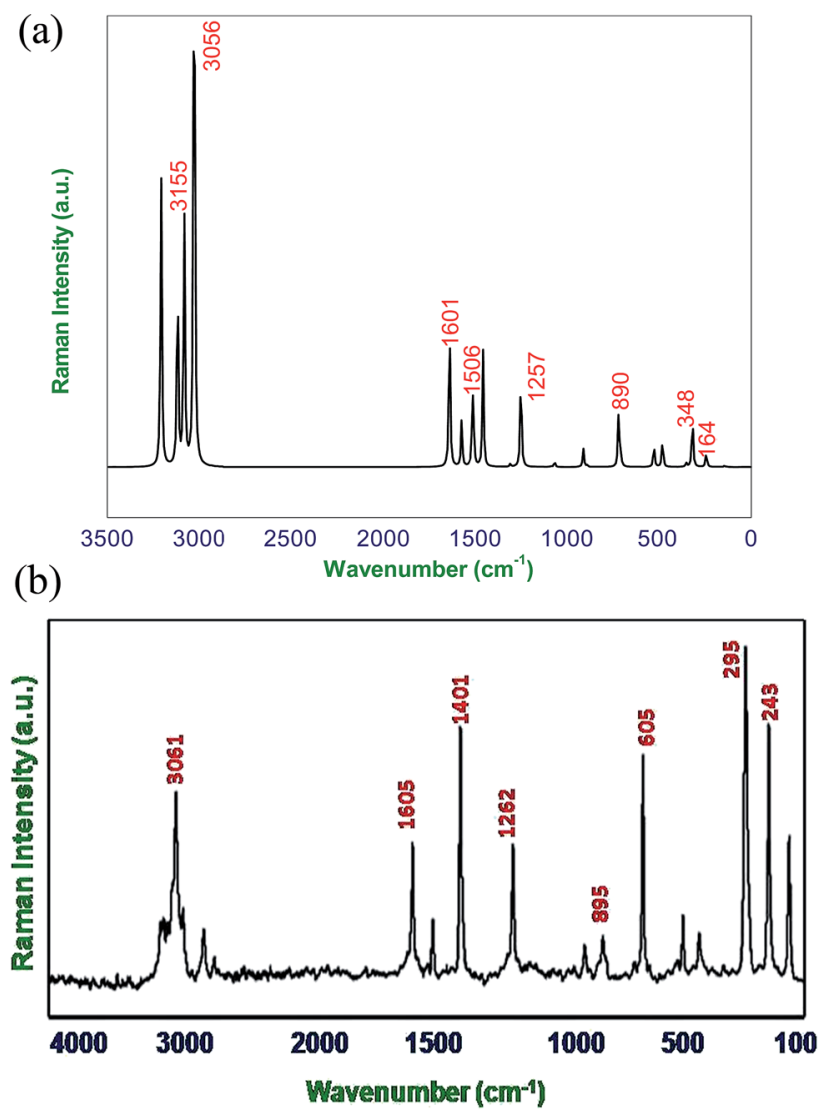

Fig. 3 (a) Calculated (B3LYP/6-311G**) FT-Raman spectra of DCPX, (b) observed FT-Raman spectra of DCPX. color indicated the strongest repulsion of DCPX towards electrophiles.

\subsection{Global molecule reactivity descriptors}

The structure-activity relationship (SAR) of a particular molecule can well be explained by calculating the global reactivity descriptors using conceptual DFT. Regarding the reactivity of a molecule, the most serious concern is the assumption the direction of reaction and the product formation in various environments. At the time of development of quantum chemical methods, there are several calculation methods have been designed for the calculation of the electronic properties of molecular systems. Among the several concepts derived the one which used to correlate the frontier molecular orbitals with reactivity of molecules designed by Fukui \& his co-workers has been utilized extensively to assume the nature of photochemical reaction. ${ }^{45}$ Meanwhile, Pearson has derived the HSAB concept to explore the reactivity of acids and bases through their hardness and softness. Pearson stated that, there will be an enhanced stabilization when the soft acid and hard acid combine with soft base and hard base, respectively. ${ }^{46,47}$ HSAB principle is one of the most prominent concepts as it covers almost all the acid-base reactions and it has been become very popular due to the applicability and simplicity.

DFT methods stay better than conventional ab initio method because of economy ratio. The most quantum chemical methods are hybrid DFT based B3LYP functional level which predicts the global and local reactivity descriptors. The value of this innovative molecular reactivity quantity has newly been demonstrated in considerate the toxicity of a range of pollutants in terms of their molecular reactivity and site selectivity. ${ }^{\mathbf{4 8 4 9}}$ The quantum chemical parameters calculated using DFT with B3LYP/6-311G** functional viz., molecular orbital energies (HOMO and LUMO), energy gap $(\Delta E)$, electron affinity (EA), ionization potential (IP), global hardness $(\eta)$, dipole moment

Table 3 Calculated chemical shifts of carbon atoms and hydrogen atoms of DCPX using TMS B3LYP/6-311G* (2d, p) and TMS HF/6-31G (d) GIAO methods

\begin{tabular}{llll}
\hline Atoms & $\begin{array}{l}\text { Experimental chemical } \\
\text { shift }(\mathrm{ppm})\end{array}$ & $\begin{array}{l}\text { TMS B3LYP/6-311G* } \\
(2 \mathrm{~d}, \mathrm{p})\end{array}$ & $\begin{array}{l}\text { TMS HF/6-31G } \\
\text { (d) GIAO }\end{array}$ \\
\hline $\mathrm{C}_{1}$ & 138.56 & 137.526 & 155.05 \\
$\mathrm{C}_{2}$ & 135.12 & 145.241 & 162.72 \\
$\mathrm{C}_{3}$ & 132.24 & 128.239 & 146.42 \\
$\mathrm{C}_{4}$ & 131.15 & 137.526 & 155.05 \\
$\mathrm{C}_{5}$ & 128.24 & 145.241 & 162.72 \\
$\mathrm{C}_{6}$ & 119.21 & 128.239 & 146.42 \\
$\mathrm{C}_{11}$ & 20.9 & 12.92 & 30.46 \\
$\mathrm{C}_{12}$ & 20.9 & 12.92 & 30.46 \\
$\mathrm{H}_{7}$ & 7.04 & 6.069 & 6.784 \\
$\mathrm{H}_{8}$ & 7.02 & 6.069 & 6.784 \\
$\mathrm{H}_{13}$ & 2.29 & 1.209 & 1.925 \\
$\mathrm{H}_{14}$ & 2.24 & 0.839 & 1.554 \\
$\mathrm{H}_{15}$ & 2.12 & 0.449 & 1.164 \\
$\mathrm{H}_{16}$ & 2.22 & 0.839 & 1.554 \\
$\mathrm{H}_{17}$ & 2.03 & 0.449 & 1.164 \\
$\mathrm{H}_{18}$ & 2.25 & 1.209 & 1.925
\end{tabular}


Table 4 Second order perturbation theory analysis of DCPX using B3LYP/6-311G** functional

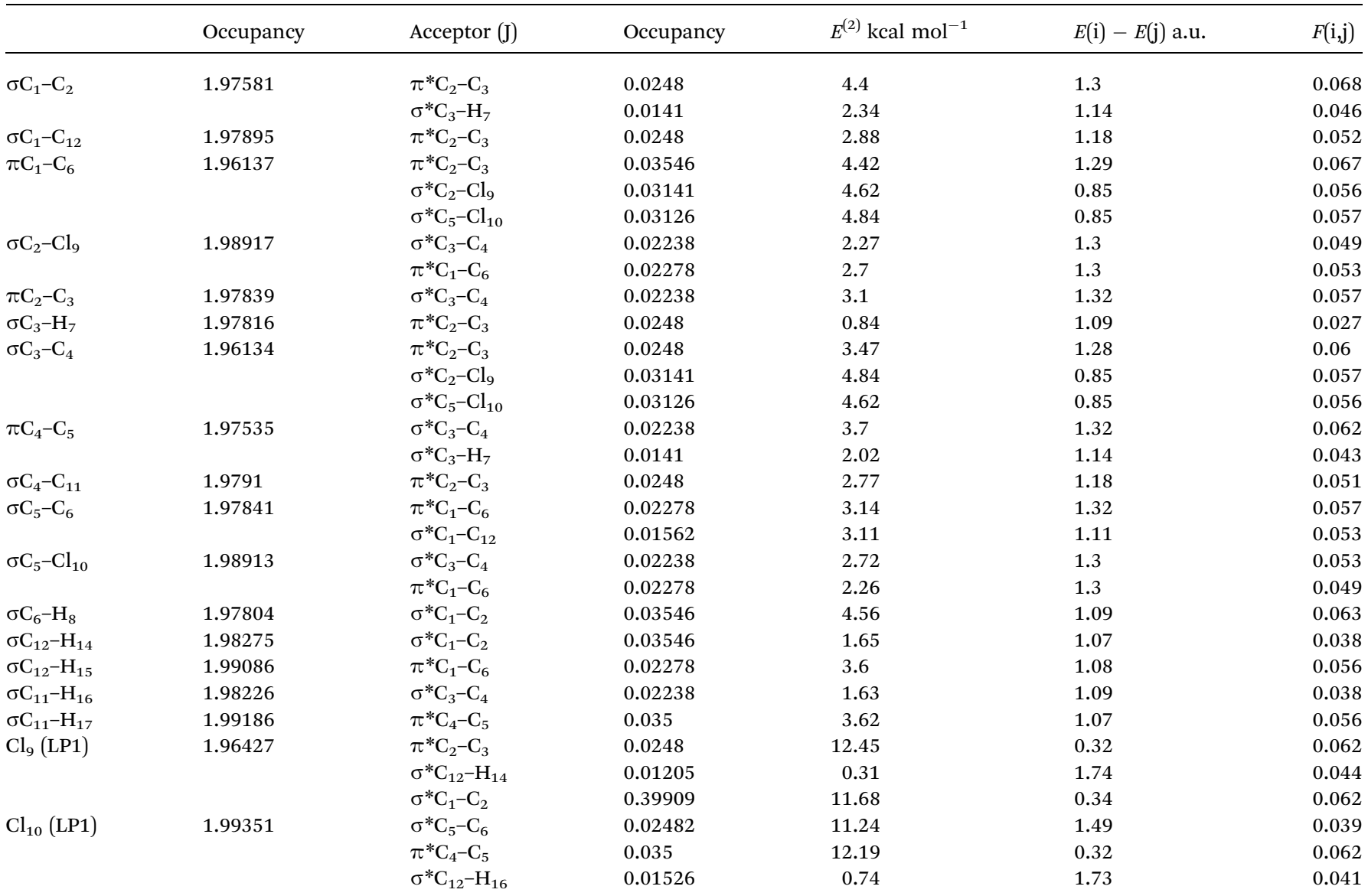

$(\mu)$, global softness $(\sigma)$, absolute electronegativity $(\chi)$ and electrophilicity index $(\omega)$ are listed in Table 5.

The molecular energies of HOMO and LUMO are related to the IP and EA, respectively in the framework of Koopmans' theorem. ${ }^{48}$

$$
\begin{gathered}
\mathrm{IP}=-E_{\mathrm{HOMO}} \\
\mathrm{EA}=-E_{\mathrm{LUMO}}
\end{gathered}
$$

Using Koopman's theorem for closed shell molecules $\eta, \mu$ and $\chi$ can be redefined as

$$
\begin{gathered}
\chi=\frac{\mathrm{IP}+\mathrm{EA}}{2} \\
\mu=\frac{E_{\mathrm{HOMO}}+E_{\mathrm{LUMO}}}{2} \\
\eta=\frac{\mathrm{IP}-\mathrm{EA}}{2}
\end{gathered}
$$

The $\sigma$ is defined as the inverse of the $\eta$ eqn (8).

$$
\sigma=\frac{1}{\eta}
$$

The electrophilicity index $(\omega)$ formula is

$$
\omega=\frac{\mu^{2}}{2 \eta}
$$

In addition, he described the nucleophilicity $(\varepsilon)$ as the multiplicative inverse of electrophilicity $(\varepsilon=1 / \omega)$.

The chemical hardness and softness of DCPX is clue of the stability of the molecule. Molecules having low energy gap are called as soft molecules which are polarisable, whereas molecules having high energy gap are called as hard molecules which are less polarisable (non-polar). From the Table 5, it is clear that, DCPX having larger energy gap. The values denoted DCPX as hard and less polarisable (non-polar) molecule.

\subsection{HOMO and LUMO analysis}

Molecules having conjugated electrons are recognized as hyperpolarisabilities and are analyzed in terms of vibrational spectroscopy. In several cases, even in the absence of an inversion center, the intense bands in the Raman spectrum are broad in the IR spectrum and vice versa. But the intra-molecular charge transfer from the donor to accepter group through a singledouble-bond conjugated path can induce large variations of both the molecular dipole moment and the molecular polarisability, making IR and Raman activity strong at the same time. 


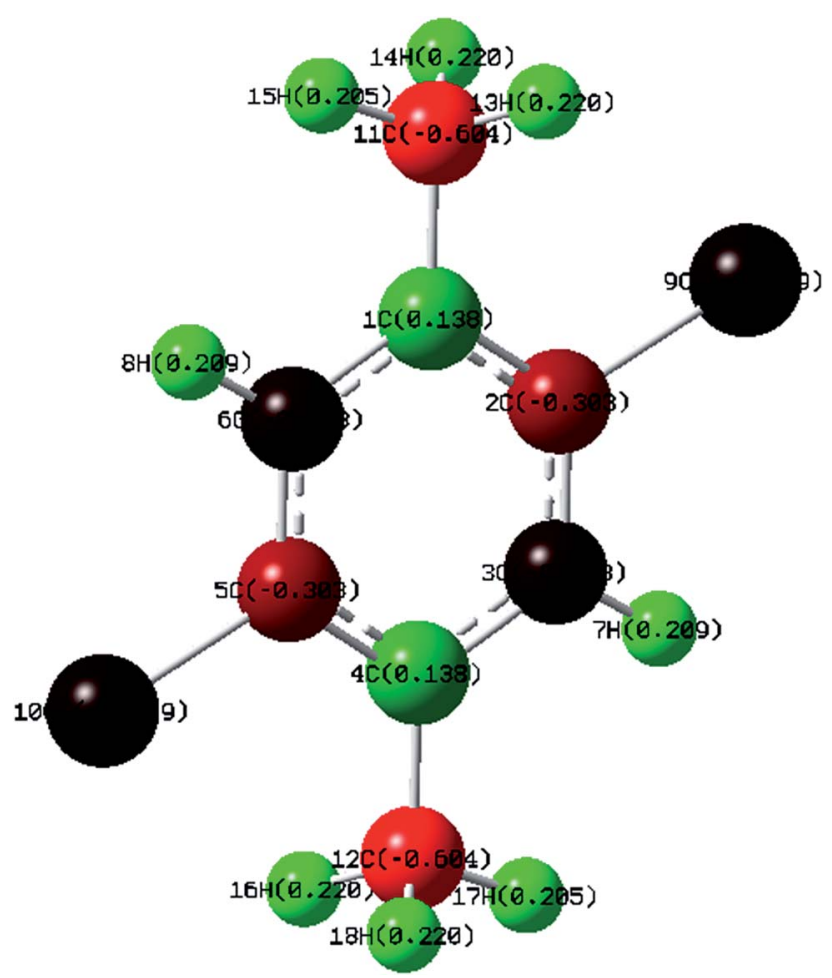

Fig. 4 Calculated Mulliken atomic charges of DCPX.

The above said experimental spectroscopic behavior can well be correlated using DFT calculations in conjugated systems which assume large Raman and infrared intensities for the similar normal modes. It is also observed in the present study that the bands in FT-IR spectrum have their counterparts in the Raman which reveals that the relative intensities in both the spectra are reliable and also explains the result from the movement of electron cloud via $\pi$ conjugated electron donor to acceptor species.

The transition of electrons from ground state to first excited state due to the absorption by means of one electron excitation from the HOMO to LUMO has been known from the wave function analysis. The Gauss Sum program is used to obtain
DOS diagram which was drawn by plotting molecular orbital data. The DOS diagram ${ }^{50}$ of DCPX is shown in Fig. 5. It is well known that chemical stability of a molecule is largely affected by the frontier orbitals. The electron donating capability of a molecule can be explained by HOMO-LUMO energy. Thus, it is assumed that the energy gap between the HOMO and LUMO reveals the molecules reactivity.

Fig. 6 shows the energy of HOMO-LUMO energy gap $(\Delta E)$ of DCPX. The calculated HOMO-LUMO energy gap of the DCPX is 12.06, 12.23, 10.49, 5.92, 6.07, 5.96 and 12.10, 12.26, 10.60, 5.98, 6.12, $6.03 \mathrm{eV}$ at the HF/SDD, HF/6-311G, HF/6-31G++, B3LYP/ SDD, B3LYP/6-311G++, B3LYP/6-31++G (Gaseous phase) and HF/SDD, HF/6-311G, HF/6-31G++, B3LYP/SDD, B3LYP/6$311 \mathrm{G}++$, B3LYP/6-31++G levels (aqueous phase), respectively. Hence, this value revealed that DCPX has relatively less kinetic stability than other derivatives. Orbitals involved in the electronic transition of (a) HOMO-0 (b) LUMO+0 (c) HOMO-1 (d) LUMO+1 (e) LUMO+2 are represented in Fig. S3 in ESI. $\dagger$ The NLO responses can be understood by examining the energies of frontier molecular orbitals. There is an inverse relationship between hyperpolarizability and HOMO-LUMO.

\subsection{First-order hyperpolarizability calculations}

Under the applied electric field, first-order hyperpolarizability (a third rank tensor) can be described by a $3 \times 3 \times 3$ matrix. The Kleinman symmetry reduces the components of the $3 \mathrm{D}$ matrix to 10 components. ${ }^{51}$ The lower tetrahedral format can be used to explain the matrix. It is very clear that, the tetrahedral's lower part is $3 \times 3 \times 3$ matrix. The calculation of NLO properties with high accuracy is challenging and requires consideration of many different issues. Computational techniques are becoming valuable in designing, modeling and screening novel NLO materials. The hyperpolarizability of DCPX is $11.583 \times 10^{-30}$ esu (calculated) which is sixty times greater than that of urea $\left(0.1947 \times 10^{-30} \mathrm{esu}\right)$. From the observation, it is clear that DCPX having NLO properties. The dipole moment and hyperpolarizability values are listed in Table S5 in ESI. $\dagger$ Oscillator strength, electronic excitation energies and nature of the respective excited states were calculated by the closed-shell

Table 5 Chemical parameters of DCPX in gaseous phase as well as aqueous phase calculated using various methods

\begin{tabular}{|c|c|c|c|c|c|c|c|c|c|c|}
\hline Methods & $E_{\text {номо }}(\mathrm{eV})$ & $E_{\text {LUMO }}(\mathrm{eV})$ & $I$ & $A$ & $\Delta E$ & $\eta$ & $\sigma$ & $\chi$ & $\omega$ & $\varepsilon$ \\
\hline $\mathrm{HF} / \mathrm{SDD}$ & -9.35154 & 2.71436 & 9.35154 & -2.71436 & 12.06590 & 6.03295 & 0.16576 & 3.31859 & 0.91274 & 1.09560 \\
\hline $\mathrm{HF} / 6-311 \mathrm{G}$ & -9.40895 & 2.82837 & 9.40895 & -2.82837 & 12.23733 & 6.11866 & 0.16343 & 3.29029 & 0.88467 & 1.13036 \\
\hline $\mathrm{HF} / 6-31++\mathrm{G}$ & -9.37385 & 1.11704 & 9.37385 & -1.11704 & 10.49089 & 5.24544 & 0.19064 & 4.12841 & 1.62462 & 0.61553 \\
\hline B3LYP/SDD & -6.77569 & -0.84628 & 6.77569 & 0.84628 & 5.92941 & 2.96470 & 0.33730 & 3.81098 & 2.44942 & 0.40826 \\
\hline B3LYP/6-311G++ & -7.00209 & -0.92792 & 7.00209 & 0.92792 & 6.07417 & 3.03709 & 0.32926 & 3.96500 & 2.58821 & 0.38637 \\
\hline B3LYP/6-31++G & -6.94440 & -0.97690 & 6.94440 & 0.97690 & 5.96750 & 2.98375 & 0.33515 & 3.96065 & 2.62869 & 0.38042 \\
\hline \multicolumn{11}{|c|}{ DCPX/aqueous phase } \\
\hline $\mathrm{HF} / \mathrm{SDD}$ & -9.36705 & 2.73939 & 9.36705 & -2.73939 & 12.10644 & 6.05322 & 0.16520 & 3.31383 & 0.90708 & 1.10244 \\
\hline $\mathrm{HF} / 6-311 \mathrm{G}$ & -9.41004 & 2.85014 & 9.41004 & -2.85014 & 12.26019 & 6.13009 & 0.16313 & 3.27995 & 0.87748 & 1.13963 \\
\hline $\mathrm{HF} / 6-31++\mathrm{G}$ & -9.37304 & 1.23405 & 9.37304 & -1.23405 & 10.60708 & 5.30354 & 0.18855 & 4.06949 & 1.56130 & 0.64049 \\
\hline B3LYP/SDD & -6.84834 & -0.86669 & 6.84834 & 0.86669 & 5.98165 & 2.99083 & 0.33436 & 3.85752 & 2.48768 & 0.40198 \\
\hline B3LYP/6-311G++ & -7.04263 & -0.91404 & 7.04263 & 0.91404 & 6.12860 & 3.06430 & 0.32634 & 3.97834 & 2.58251 & 0.38722 \\
\hline B3LYP/6-31++G & -6.96780 & -0.93445 & 6.96780 & 0.93445 & 6.03336 & 3.01668 & 0.33149 & 3.95112 & 2.58751 & 0.38647 \\
\hline
\end{tabular}




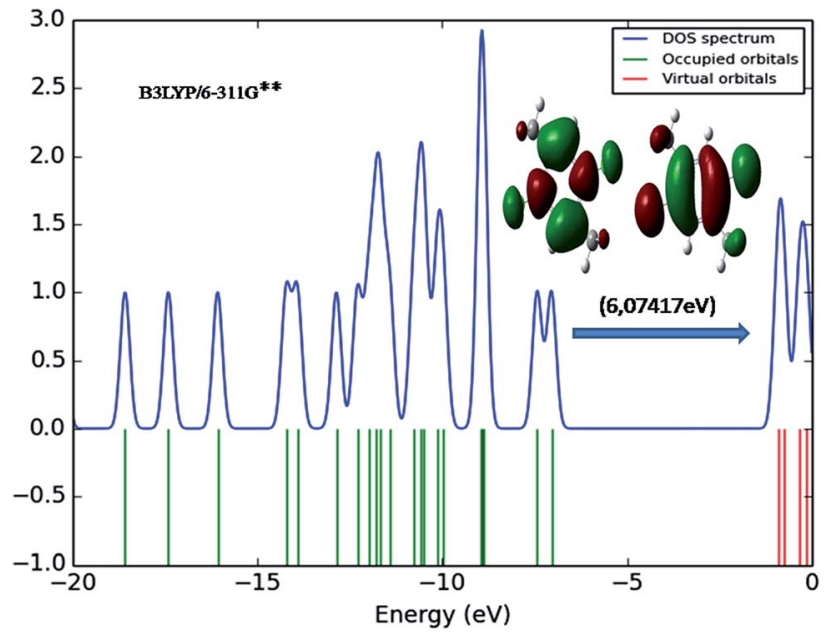

Fig. 5 DOS diagram representation of HOMO (left) and LUMO (right) of DCPX.

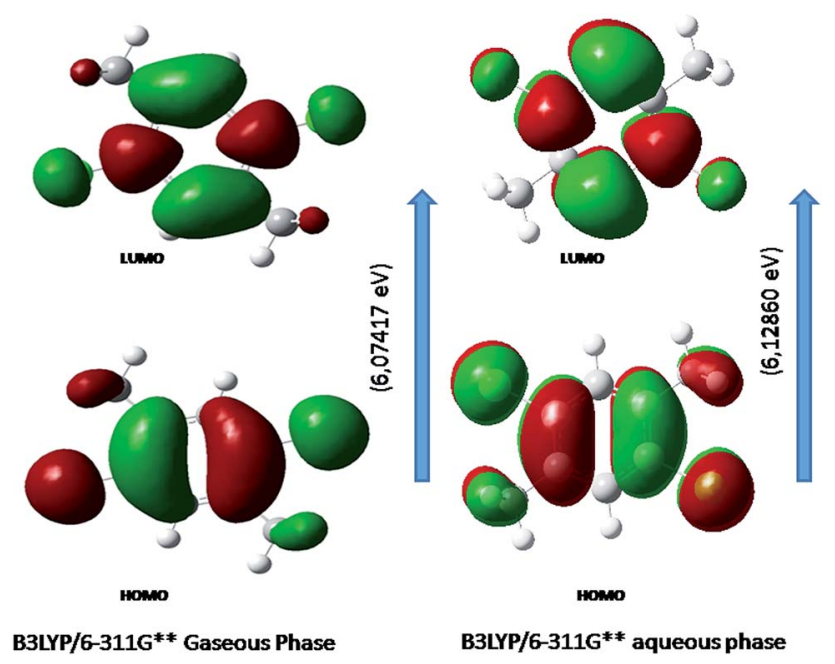

Fig. 6 Representation of the orbitals involved in the electronic transition of DCPX for HOMO and LUMO.

singlet calculation method and are summarized in Table S6 of ESI. $\dagger$ Table S6† clearly indicated the higher first static polarizability of DCPX.

\section{Conclusions}

The symmetry of DCPX has been identified as $C_{\mathrm{s}}$ point group from the optimized structure. In addition, the bond lengths and bond angels of all atoms of DCPX have also been calculated. The difference in bond lengths of various substituents has been due to the inductive and resonance effects in DCPX. The 48 normal modes of DCPX were calculated using DFT coupled with B3LYP/ 6-311 $+\mathrm{G}^{* *}$ functional. Computed vibrational modes include FTIR and FT-Raman was compared with experimentally observed values and which is in quite agreement with each other. The very least mean deviation of about $7.09 \mathrm{~cm}^{-1}$ for DCPX has been observed after the least square refinement of the scale factors validated the adoption of B3LYP method. The structural features of DCPX have been confirmed from the results of NMR spectral analysis. The occurrence of intra-molecular hydrogen bonding in DCPX has been confirmed from NBO analysis in addition to biological activity. The charge distribution of DCPX is known from Mulliken population analysis. The positive and negative regions followed by nucleophilic and electrophilic reactive centres have been identified from MEP analysis. The SAR of DCPX based on global reactivity descriptors suggested DCPX as hard and non-polar species. The HOMO-LUMO analysis of DCPX revealed the donor-acceptor nature, reactivity and NLO property of DCPX. Further, the NLO property of DCPX has been supported by the observation of larger hyperpolarizability value.

\section{References}

1 R. Vedula, S. Kaza and S. B. Desu, in Chemical Vapor Deposition, ed. J. H. Park and T. S. Sudarshan, ASM International, Ohio2, vol. 43, 2001.

2 M. E. Vaschetto, B. A. Retamal and A. P. Monkman, J. Mol. Struct.: THEOCHEM, 1999, 468, 209-221.

3 V. Arjunan, I. Saravanan, C. V. Mythili, K. Balakrishnan and S. Mohan, Spectrochim. Acta, Part A, 2012, 91, 166-177.

4 K. Kimura, J. Electron Spectrosc. Relat. Phenom., 1999, 100, 273.

5 P. J. Breen, J. A. Warren and E. R. Bernstein, J. Chem. Phys., 1987, 87, 1917-1935.

6 K. Walter, K. Scherm and U. Boesl, Chem. Phys. Lett., 1989, 161, 473-478.

7 A. P. Singh, S. Sharma and S. M. Kale, J. Mol. Catal. A: Chem., 1997, 127, 101-111.

8 C. E. H. Dessent and K. Muller-Dethlefs, Chem. Rev., 2000, 100, 3999-4021.

9 M. Govindarajan, K. Ganasan, S. Periandy, M. Karabacak and S. Mohan, Spectrochim. Acta, Part A, 2010, 77, 1005-1013.

10 V. Arjunan, P. S. Balamourougane, I. Saravanan and S. Mohan, Spectrochim. Acta, Part A, 2009, 74, 798-807.

11 M. Govindarajan and M. Karabacak, Spectrochim. Acta, Part A, 2012, 94, 36-47.

12 M. Manzoor ali, G. George, S. Ramalingam, S. Periandy and V. Gokulakrishnan, J. Mol. Struct., 2016, 1106, 36-52.

13 M. Arivazhagan and R. Meenakshi, Spectrochim. Acta, Part A, 2012, 91, 419-430.

14 C. Lee, W. Yang and R. G. Parr, Phys. Rev., 1988, 1337, 785. 15 A. D. Becke, J. Chem. Phys., 1993, 98, 5648.

16 R. Meenakshi, RSC Adv., 2016, 6, 21821-21832.

17 S. Mary, V. V. Aswathy, P. C. Yohannan, A. Bielenica, P. Brzózka, O. Savczenko, S. Armaković, S. J. Armaković and C. V. Alsenoy, RSC Adv., 2016, 6, 111997-112015.

18 R. Meenakshi, RSC Adv., 2016, 6, 63690-63703.

19 M. J. Frisch, G. W. Trucks, H. B. Schlegel, G. E. Scuseria, M. A. Robb, J. R. Cheeseman, J. A. Montgomery Jr, T. Vreven, K. N. Kudin, J. C. Burant, J. M. Millam, S. S. Iyengar, J. Tomasi, V. Barone, B. Mennucci, M. Cossi, G. Scalmani, N. Rega, G. A. Petersson, H. Nakatsuji, M. Hada, M. Ehara, K. Toyota, R. Fukuda, J. Asegawa, 
M. Ishida, T. Nakajima, Y. Honda, O. Kitao, H. Nakai, M. Klene, X. Li, J. E. Knox, H. P. Hratchian, J. B. Cross, C. Adamo, J. Jaramillo, R. Gomperts, R. E. Stratmann, O. Yazyev, A. J. Austin, R. Cammi, C. Pomelli, J. W. Ochterski, P. Y. Ayala, K. Morokuma, G. A. Voth, P. Salvador, J. J. Dannenberg, V. G. Zakrzewski, S. Dapprich, A. D. Daniels, M. C. Strain, O. Farkas, D. K. Malick, A. D. Rabuck, K. Raghavachari, J. B. Foresman, J. V. Ortiz, Q. Cui, A. G. Baboul, S. Clifford, J. Ioslowski, B. B. Stefanov, G. Liu, A. Liashenko, P. Piskorz, I. Komaromi, R. L. Martin, D. J. Fox, T. Keith, M. A. AlLaham, C. Y. Peng, A. Nanayakkara, M. Challacombe, P. M. W. Gill, B. Johnson, W. Chen, M. W. Wong, C. Gonzalez and J. A. Pople, Gaussian 03, Revision E.01, Gaussian Inc., Pittsburgh. B.A, 2000.

20 S. Ramalingam, S. Periandy, B. Elanchezhian and S. Mohand, Spectrochim. Acta, Part A, 2011, 78, 429-436.

21 E. B. Wilson Jr, J. C. Decius and P. C. Cross, Molecular Vibrations, MecGraw Hill, New York, 1955.

22 C. J. Pouchert, The Aldric Library of FT-IR spectra, Aldrich Chemicals Co., Milwaukee, WI, 1985.

23 P. Pulay, G. Fogarasi, G. Pongar, J. E. Boggs and A. Vargha, J. Am. Chem. Soc., 1983, 105, 7073.

24 G. Fogarasi, X. Zhou, P. W. Jaylor and P. Pulay, J. Am. Chem. Soc., 1992, 114, 819.

25 P. Vennila, M. Govidaraju, G. Venkatesh and C. Kamal, J. Mol. Struct., 2016, 1111, 151-156.

26 S. Ramalingam, S. Periandy, B. Narayanan and S. Mohan, Spectrochim. Acta, Part A, 2010, 76, 84-92.

27 V. Krishnakumar and R. John Xavier, Indian J. Pure Appl. Phys., 2003, 41, 95-98.

28 N. Sundaraganesan, B. Anand, C. Meganathan and B. D. Joshua, Spectrochim. Acta, Part A, 2007, 68, 561-566.

29 M. Arivazhagan and R. Meenakshi, Spectrochim. Acta, Part A, 2012, 91, 419-430.

30 G. Varsanyi and S. Szoke, Vibrational Spectra of Benzene Derivatives, Academic Press, New York, 1969.
31 G. Socrates, Infrared and Raman Characteristic Group Frequencies-Tables and Charts, Wiley, New York, 3rd edn, 2001.

32 V. Krishnakumar, N. Prabavathi and S. Muthunatesan, Spectrochim. Acta, Part A, 2008, 70, 991-996.

33 K. Haruna, A. A. Alenaizan and A. A. Al-Saadi, RSC Adv., 2016, 6, 67794-67804.

34 P. B. Nagabalasubramanian, S. Periandy and S. Mohan, Spectrochim. Acta, Part A, 2010, 77, 150.

35 S. Sebastian, N. Sundaraganesan, B. Karthikeiyan and V. Srinivasan, Spectrochim. Acta, Part A, 2011, 78, 590-600.

36 S. P. Saravanan, A. Sankar and K. Parimala, J. Mol. Struct., 2017, 1127, 784-795.

37 S. Higuchi, Spectrochim. Acta, Part A, 1974, 30, 463-467.

38 J. Murto, Spectrochim. Acta, Part A, 1973, 29, 1125.

39 N. F. Chamberlain, The Practice of NMR Spectroscopy with Spectra Structure Correlations for Hydrogen-1, Plenum Press, 1974.

40 H. E. Gottlieb, V. Kotlyar and A. Nudelman, J. Org. Chem., 1997, 62, 7512-7515.

41 G. Venkatesh, M. Govindaraju and P. Vennila, Indian J. Chem., 2016, 55, 413-422.

42 C. James, A. Amal Raj, R. Reghunathan, I. H. Joe and V. S. Jayakumar, J. Raman Spectrosc., 2006, 37, 1381-1392.

43 K. Parimala and V. Balachandran, Spectrochim. Acta, Part A, 2013, 110, 269-284.

44 S. Miertus, E. Scrocco and J. Tomasi, Theor. Chem. Acc., 2000, 103, 343-345.

45 W. Yang and R. G. Parr, Hardness, softness and the Fukui function in the electronic theory of metals and catalysis, Proc. Natl. Acad. Sci. U. S. A., 1985, 82, 6723-6726.

46 R. G. Pearson, J. Am. Chem. Soc., 1963, 85, 3533.

47 R. G. Pearson, Inorg. Chem., 1988, 27, 734.

48 T. Koopmans, Physica, 1933, 1, 104.

49 S. Kaya and C. Kaya, Mol. Phys., 2015, 113, 1311.

50 N. M. O'Boyle, A. L. Tenderholt and K. M. Langner, J. Comput. Chem., 2008, 29, 839-845.

51 D. A. Kleinman, Phys. Rev., 1962, 126, 1977. 